\title{
Geochemical and Geodynamic Constrain of Tholeiitic Volcanism and Related Intrusions in the Kampti Gold District, Southwest Burkina Faso: Implication for Mineral Exploration
}

\author{
Mathieu Nanema ${ }^{1}$, Urbain Wenmenga ${ }^{1} \&$ Hermann Ilboudo ${ }^{2}$ \\ ${ }^{1}$ Laboratoire de Géoressources, Université Ouagadougou I Pr. Joseph Ki Zerbo, Burkina Faso \\ ${ }^{2}$ Laboratoire de Géosciences et environnement minier, Université Ouagadougou I Pr. Joseph Ki Zerbo, Burkina \\ Faso \\ Correspondence: Mathieu Nanema, Laboratoire de Géoressources, Département des Sciences de la Terre, \\ Université Ouagadougou I Pr. Joseph Ki-Zerbo, 03 BP 7021 Ouagadougou 03 UFR/SVT, Burkina-Faso. Tel: 226- \\ 7018-0656. E-mail: nanemageologue@gmail.com
}

Received: December 5, 2017

Accepted: December 14, 2017 Online Published: December 30, 2017

doi:10.5539/esr.v7n1p76

URL: https://doi.org/10.5539/esr.v7n1p76

\begin{abstract}
The Kampti serie is a volcano-plutonic complex in the south-eastern corner of the Houndé belt, closed to the border with Ivory Coast. The stratigraphy comprises initially: a thick sequence of tholeiitic and pillowed basalt followed by pyroclastic projections derivated from bimodal volcanism; and flowing mostly to the south. The volcanic sequence is cross-cut by mafic cumulate body, stocks of gabbro, diorite, subvolcanic dykes and lately intrude by granitoid. It is bordered to the west by the pelitic schist of the Bambela basin with minor intercalation of Tarkwa type sediment. volcanoclastic facies is dominantly plagioclase-phyric (albite $+/$ - oligoclase), zoned plagioclase has a core of anorthoclase. Secondary mineral infilled (quartz, kutnahorite, ripidolite, clinozoisite) of spherulites and oolite highlight a general low grade metamorphism of greenschist facies affecting the complex.

Based on trace element chemistry, the tholeiitic rocks present flat REE pattern contrasting with the felsic rocks more enriched in LREE and depleted in HREE. The style of the magmatism in the Kampti serie is compatible with an island arc model, describe elsewhere in the birimian. Gold mineralisation and base metal occurrences associated to the nature of rocks and tectonics highlight a polymetallic district.
\end{abstract}

Keywords: Burkina Faso, Kampti, granites, tholeiitic, calc-alkaline, greenschist, projections, gold, Leo shield

\section{Introduction}

South west Burkina Faso is suggested to intense gold rush, especially in the Houndé belt. Three-word class deposits $(120 \mathrm{Mt})$ have been defined and currently being operated within the volcanic-sediment. Their locations are closed to tholeiitic basalt in the stratigraphy. The gold and base metals are closely associated and structured along tectonic faults. Recent study in the mana gold district (Augustin and Gaboury, 2017) imply a model of plume-related tholeiitic basalt which is supposed to be primarily enriched in gold than the MORB-related basalt. This enrichment is suggested to be the primary source of the gold, subsequently concentrated along fault to define economic deposit. The paper presented here focus on the south-eastern end of the same belt. We constrain the petrology and geochemical features and discuss the geodynamic of the magma setting with respect of the works done previously on the same belt. An inventory of the mineral assets is presented on map to show key relationship between tectonic, rock type and occurrences similarly to other districts on the belt.

\section{Geological Setting}

The Leo shield forms the southern basement of the Western African craton and cover six countries (Burkina Faso, Ivory coast, Guinea, Ghana, Mali and Senegal). It comprises a western domain Kenema-Man of Archean age strongly metamorphosed and an eastern domain Baoulé-Mossi of paleoproterozoic age, separated by a transition zone along the Sassandra fault (Figure 1). The paleoproterozoic domain where is located the area of study in south west Burkina Faso, comprises birimian rocks affected by the eburnean orogenesis $(2.2 \mathrm{Ga}-2 \mathrm{Ga})$. The paroxysm of the deformation is situated around 2.1 to 2.09 Ga (Einsenlohr et Hirdes, 1992). 
In Burkina Faso, the Paleoproterozoic rocks cover $80 \%$ of the country and the rest is represented by the Neoproterozoic to Paleozoic sediment in the NW and further NE of the border. the greenstones belts aged of $2.25-1.9 \mathrm{Ga}$ (Bessoles, 1977; Lemoine, 1988; Boher et al., 1992; Sattran \& Wenmenga, 2002; Castaing et al., 2003) are linear and plurikilometric, made-up of early volcanic flow and derived product reworked in the centre of the basin (Leube et al., 1990). The granitoidic event ME1-ME3 sourced probably from basaltic floor introduced internal fabrics and mylonite zone at the contact of the plutons. Early transcurrent faults from NW/SE crustal scale shortening evolve to regional scale transpressional fault (mylonite zone and horsetail fault) which control the major hydrothermal fluid circulation in the birimian system. Late NE/SW strike-slip fault and NW/SE extensional vein-jogs reactivated early fabrics and add subsequent mineralisation fluid within the greenstone belts.

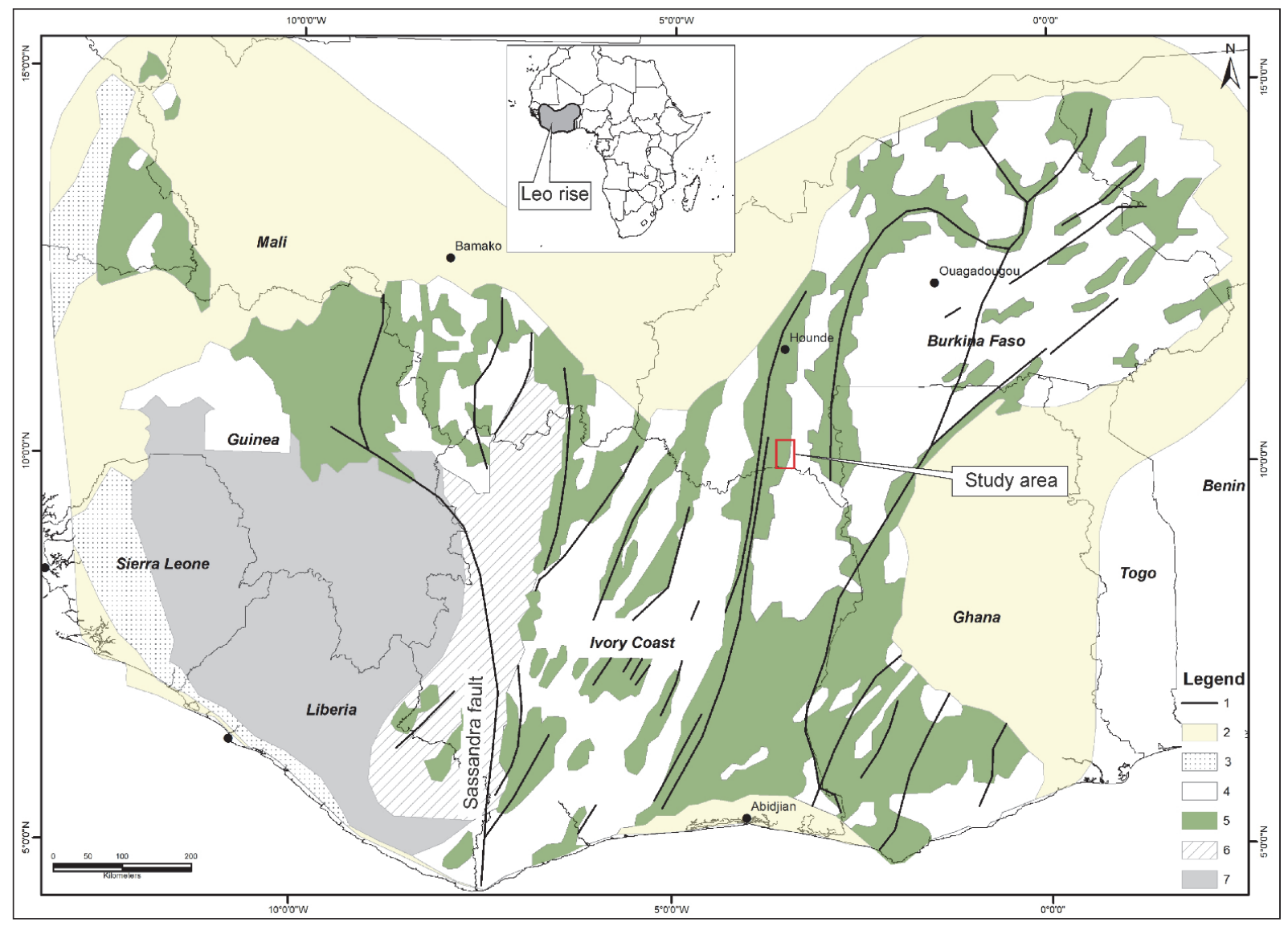

Figure 1. Geological map of the Leo shield in the West Africa Craton WAC updated from Milési et al., 2004

Legend: 1) Major fault; 2) Neoproterozoic to Phanerozoic cover; 3) panafrican mobile belt; 4) Paleoproterozoic granitoid; 5) Paleoproterozoic greenstone belt; 6) Transition zone; 7) Archean basement

The Kampti district belongs to the Houndé Belt. This belt (400km strike length) is part the major metallogenic belts of Burkina Faso strictly trending NNE to NE. This structuration is common in the overall West Africa Craton (John et al., 1999; Milési et al., 1989, 1992; Lompo, 2010; Martwitz et al., 2017). It comprises at the base a sequence of tholeiitic mafic and calc-alkaline volcanic which crops in either side of the belt margin and scarred as NE elongated strips of mountain (Figure 2a). The volcanic sequence is surmounted by pelitic metasediment (Arnould, 1950 et 1958; Ludtke et al., 1998; Marcelin, 1971) and limited sandy and conglomeratic unconformity (Bonkougou, 1994; Koffi et al., 2017). The latter sequence is suggested deriving from the former volcanic rocks by proximal erosion. 3 types of intrusions corresponding to the polycyclic magmatic events (an early tonalitetrondhjemite-granodiorite contemporaneous of the volcanic sequence; potassic amphibole-biotite and late alkali granitoid) have structured the belt (Lompo, 2010) to a NE oriented regional fabrics. NS/NNE trend regional transpressional fault of Ouango-Fitini and high strain Boni shear zone (Baratoux et al., 2015) bordered either side of the belts and control the gold occurrences. Periplutonic deformation related to diapiric batholith locally increases 
a prograde regional greenschist facies to amphibolite condition or along high strain zone.

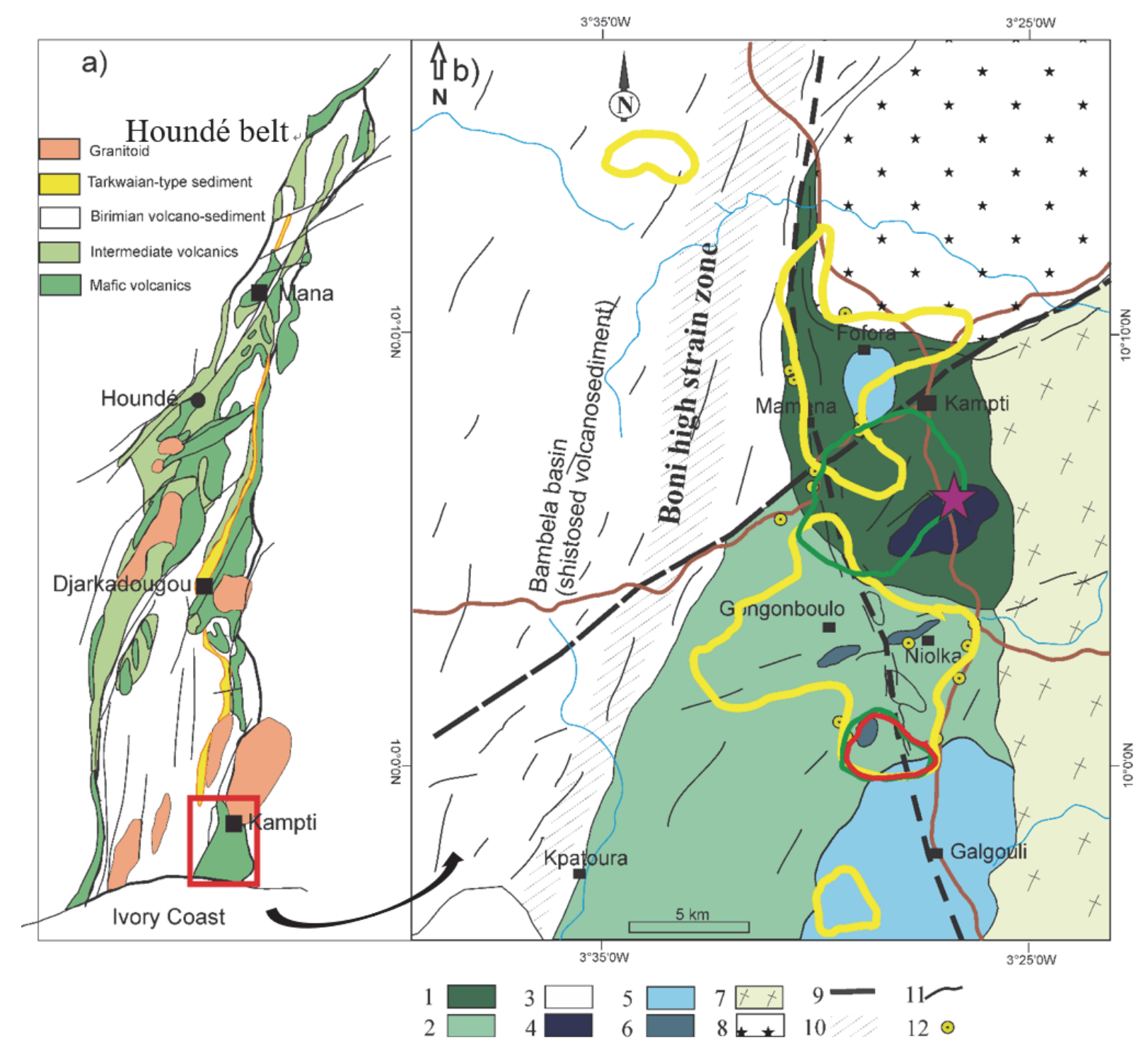

Figure 2. a) Simplified geology of the Houndé belt and b) zoom on the Kampti serie

Legend: 1) basalt; 2) volcanoclastic; 3) Bambela volcano sediment basin; 4) cumulate intrusive; 5) gabbro; 6) diorite; 7) tonalite-trondhjemite-granodiorite; 8) granite-granodiorite; 9) fault; 10) high strain zone; 11) foliation; 12) samples discussed in the text

\section{Methodology}

This paper follow-up a desktop review of the data including unpublished work from the BUMIGEB (Bureau des Mines et de la Géologie du Burkina), mining companies (Hyder gold, Volta resources now B2gold, Randgold resources) and independent consultant's data.

The field work comprised observation of 122 sites, sampled if rock exposures are fresh and describe carefully. 33 samples in rock were collected for thin section at the Université Ouaga I Professeur Joseph Ki-ZERBO. Five mineral species analysed on polished section with microphobe CAMECA SX100 at l'Université Blaise Pascal Clermont Ferrand, France (Table 1).

In completion for this petrographic and mineralogical study, 17 least altered samples (Figure $2 b$ ) were sent to Acme-Lab in Vancouver for major and trace elements analysis using the ICP-MS technics (Table 2). Additional geochemical data gathered from different papers in the Houndé belt were compiled to complete a comparison of 
the rare earth element patterns (in appendix).

\section{Results}

\subsection{Petrography and Mineralogy}

\subsubsection{Volcanic Rocks}

Volcanic rocks constitute the main formation with good exposure in the study area (Figure 2b). They represent $\sim 60 \%$ of the overall units. The rocks range from mafic to felsic, with some evidence of structural and textural figures that support the presence of flow and/or projection occurrences in places.

\subsubsection{The Basalt Flow}

The basalt outcrop as pseudo pillow (Figure 3a) or locally breccia flow. It forms northerly trend ridges suggested to gold digging in the Mamena - Fofora villages. Generally dark green when none altered, the fresh exposure is greyish or greenish grey colour when it is suggested to extensive carbonate flooding. In hand specimen the texture is aphanitic to aphyric, but microporphyric in thin section. Frequent millimetre to centimetre size amygdales are infilled with one or many minerals indicate a bullous character of lavas. Associated spherulites of actinote destabilised in chlorite and accessorily in pistachite are also bordered by carbonate and pistachite are the prominent mineral assemblage (Figure 4a). The microlite of plagioclase are mainly albite. The rare relicts of zoned plagioclase combine preserved inner core of anorthoclase and outer rim of albite (Figure 5a). Cubic, trapeze shape or euhedral opaques are disseminated in the rock; sometimes concentrated to $1-3 \%$ along epidote, quartz-carbonate vein or along foliated mineral and associated native gold. In the village of Mamena, the basalt is transformed in chlorite carbonate and quartz $+/$ - sulphide schist in relation with hypothermal fluid circulation along ductile tectonic.

\subsubsection{The Volcanoclastic Projection}

The pyroclastic projection is two times spread out than the equivalent flow to the north. These rocks are plagioclase-phyric composition of bomb size of $+60 \mathrm{~cm}$ to metric size poorly sorted and stratified tuff (Figure 3be). Thinly layered ash and finer tuffs $(1.5$ to $3.5 \mathrm{~mm})$ show frequent figures of load-cast. The crystal tuff and ignimbrite are occasionally intercalated and display tabular or cross-bedding structure. Some pillowed breccias were recorded also to the south of studied area over half kilometre extension within the brecciated tuff. The pseudopillow size two meters and cemented by a felsic lava containing strong quartz crystals.

The most common feature observed in hand specimen is the cement of these fragmental rocks is all finer grained of basalto-andesite nature. The fragments are plagioclase-phyric and polygenic or monomineral, with internal texture of cataclaste, ignimbrite, nodule and oolite (Figure 4b-e). Chilled margin and thermal fracture are limited to the clasts rounded or sub angular.

The lithic fragments are microlite flow of andesite which contain micro-phenocryst of plagioclase, crystal tuff of isogranular plagioclase and spherolitic lava and ash tuff, oolite of epidote needle pistachite+/-zoisite, carbonate and opaque, vitroclastic tuff containing oolite of quartz probably originating from felsic glass (Figure 4f-h). The mineral fragments are abundant of zoned plagioclase seizing millimetre to half centimetre, hornblende and rare orthose crystals. The groundmass is generally andesitic flow consisting of microlite of isogranular oligoclase, zoned and intensely sausuritised in albite (Figure 4e) and epidote (could be recrystallized glass shards). Aggregate of isomicrogranular volcanic oolites are infilled with quartz and secondary mineral of ripidolite, kutnahorite, muscovite, clinozoisite and rimed by sericite saussurite (Figure 5b-d).

\subsubsection{The Andesitic Flow}

It forms subordinate greyish flow intercalated within the basalt and the volcanoclastites (Figure 3f). It shares the common features observed in the basalt, such as microporphyric texture and amygdale. Microlite of albite and acicular actinote were destabilised in biotite, chlorite and epidote. Rare quartz and orthose were noted.

\subsubsection{The Subvolcanic Rocks}

It forms sheeted sills or dykes intercalated or crossing both volcanics and plutonic rocks. It ranges from dacite to rhyolite, whitish to light grey in hand specimen. The texture is micro-crystalline to micro-porphyry. It displays a common heterogranular feature, leuco to mesocratic facies of dioritic nature. Most spherulites are composed of symplectite plagioclase and orthose, plagioclase and muscovite, cortex of plagioclase with rim of orthose and phenocryst of broken plagioclase. The very fine grained groundmass is recrystallized on finer and abundant albite, sericite, muscovite, epidote and carbonate. These secondary minerals represent the saussuritization of the ancient microlite of plagioclase. The biotite is mostly destabilised in muscovite and granules of opaques. The contact of the sheeted dykes and the host rocks is infilled quartz-carbonate and sulphide vein and native gold, mined by orpaillers in the Mamena and Fofora area. 

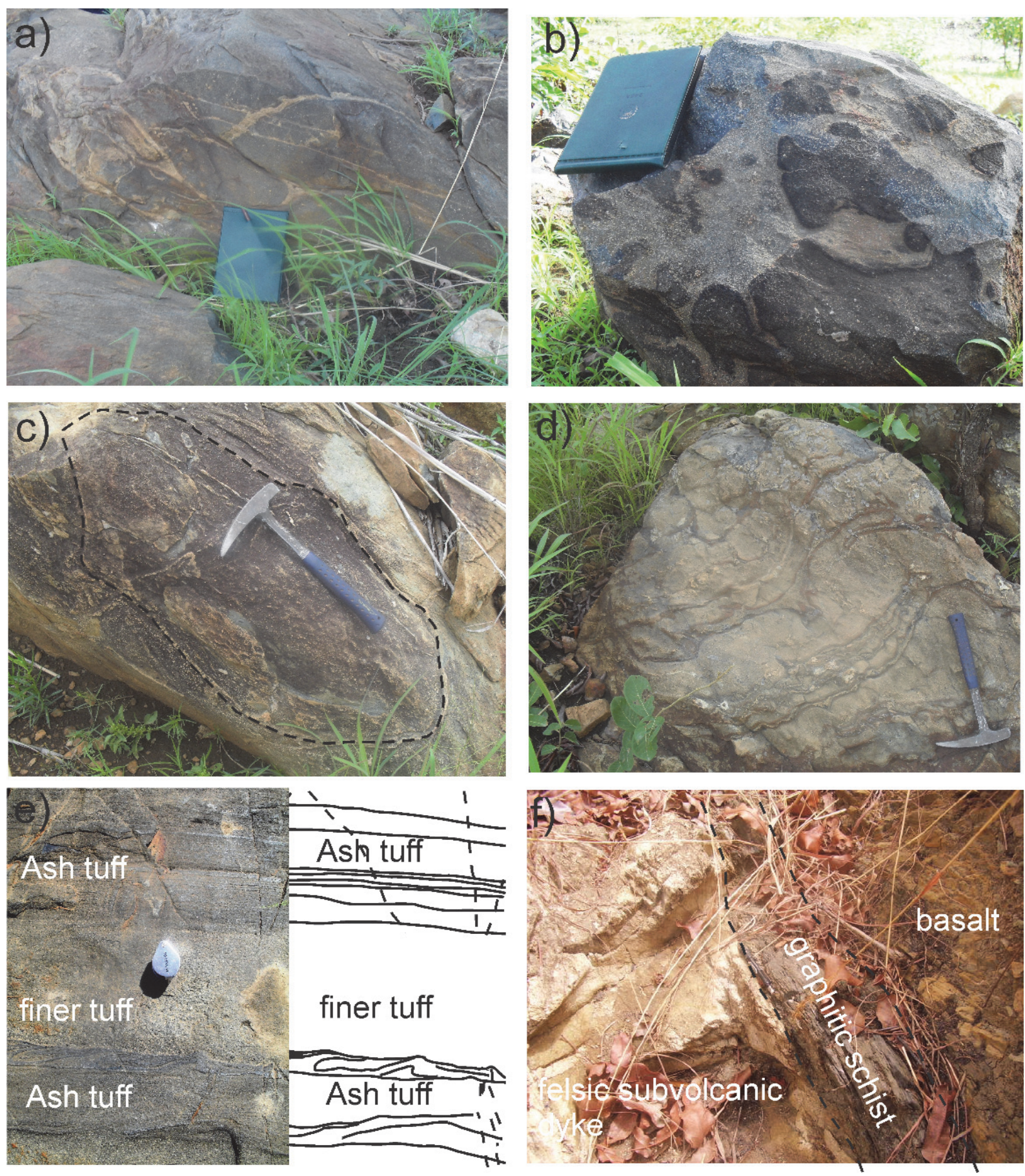

Figure 3. Macroscopic scale observation of the volcanic rocks. a) pseudo-pillowed basalt cross-cut by carbonatequartz veinlets in the Mamena localities. b) mafic breccia with feldspar phyric matrix supported decametric size clast. C) pillowed breccia with 1 to 2 meter elongated pillows along the regional NE fabric. they are cemented by felsic lava. Facies observed at the border with ivory coast Galgouli. d) load cast texture observed in medium grained tuff. e) laminated and interlayered ash and finer grain tuff showing feature of load and disturbing sedimentation. f) subvolcanic rocks are expressed as felsic dykes here along a NNW oriented shear zone in the basalt bordered by graphitic schist as a resultant of reducing hydrothermal fluid at the contact 

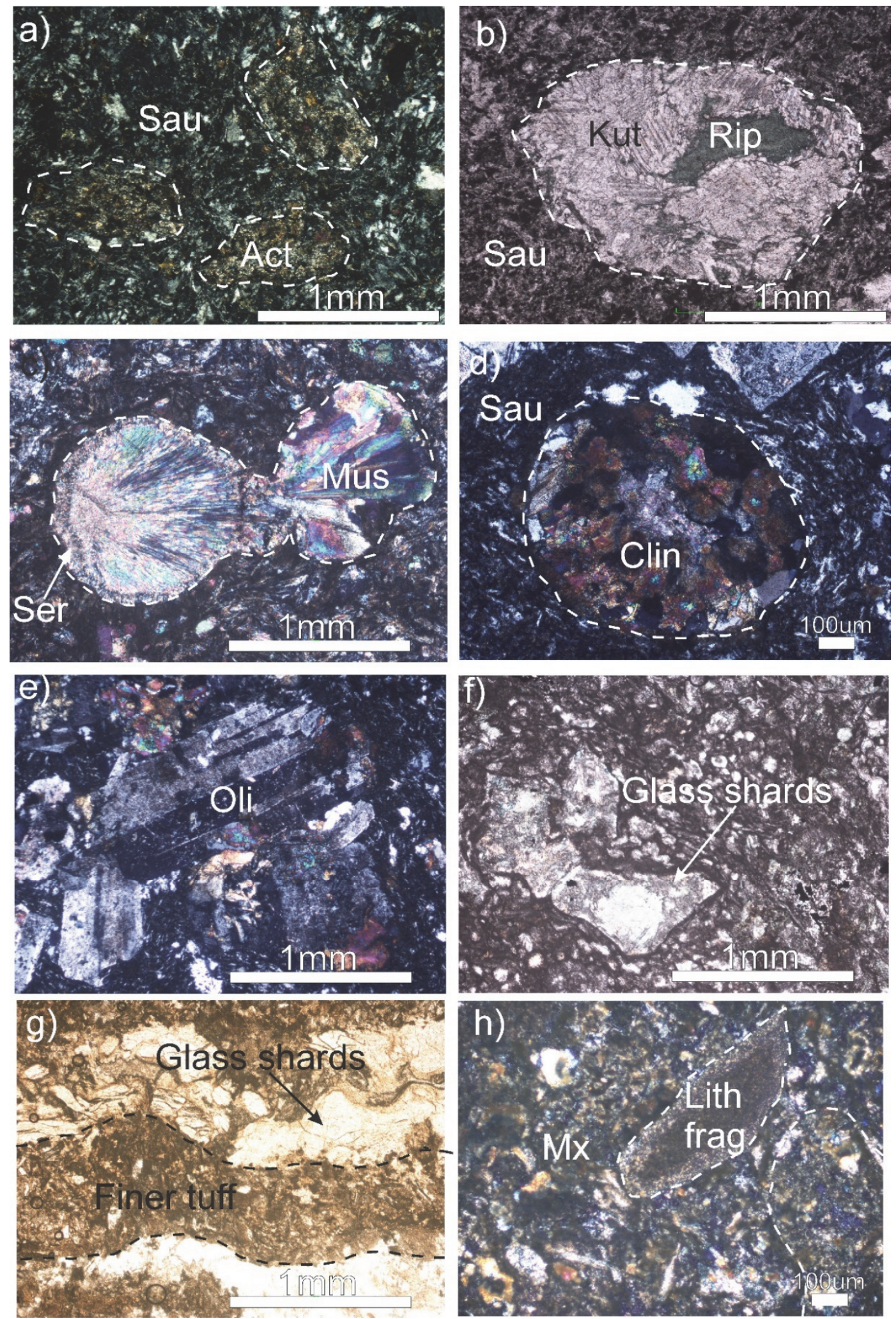

Figure 4. Microscopic scale observation of the volcanic rocks texture. a) glomeroporphyric texture in basalt with actinote (Act) in fine grained saussuritised (Sau) microlite of plagioclase. $b$ to d) spherulites and oolites infilled with secondary mineral of ripidolite (Rip), kutnahorite (Kut), muscovite (Mus), clinozoisite (Clin) and rimed by sericite (Ser)-saussurite (Sau). e) plagioclase zoning consists of inner oligoclase and albite type rim in crystal tuff. f) vitroclastic tuff with subangular glass shards. g) finely laminated layers of vitroclastic tuff and fined tuff observed in natural light. h) welded tuff of andesite fragments trapped in a fluidal matrix(Mx) of saussuritised microlite. 


\subsubsection{Intrusive Rocks}

The intrusive rocks are widespread and of variable size. From the centre of the studied area, they are mafic to felsic of elliptical shape while moving to the north, the main component is quasi-circular felsic batholith and dykes.

\subsubsection{The Mafic Intrusives}

They are elliptic bodies oriented accordingly to the birimian fabrics of decametric to plurimetric extension. Four main stocks are observable such Mamena, Kpatoura, Galgouli and Yelonhira areas. The last cited is recognisable on the field with its black lustrous appearance and identified as cumulates of gabbronorite, gabbro diorite and subordinate pyroxenolite (Nanema et al., 2016).

The others studied in this paper are common gabbro (leuco to melanocratic) of finer to medium grains. The grains are homogeneous to plagioclase-phyric like Fofora one or sub ophitic. The leuco and mesocratic type is plagioclase and amphibole rich and the melanocratic is pyroxene and plagioclase rich.

On thin section, the plagioclase minerals are mostly zoned and tabular phenocryst of intensely sausuritised in albite and epidote. The pyroxene mostly turns into hornblende, actinote, chlorite and epidote.

\subsubsection{The Dioritic Rocks}

The diorite crops out at Niolka as discontinue dyke of ENE extension within the explosive volcanics or as subcircular stocks of limited extension in the basalt flow. On hand specimen, the rock is leucocratic to mesocratic, more finely than medium grained, microporphyric, locally foliated and layered. The main mineral components are laths of plagioclase and spherulites made of green hornblende and actinote needles. The biotite is replaced by muscovite and chlorite, the calcite and quartz are filling micro cracks and vesicles. At Niolka, it contains bluish quartz, malachite, pyrite and chalcopyrite similar of copper porphyry type.

\subsubsection{The Granitoidic Intrusives}

Three type of granitoid are recorded in the Kampti area and oriented accordingly to the eburnean orogeny prevailing on that part of the belt. Based on the primary mineral components, it ranges from muscovite-, biotiteand biotite - amphibole granite and localised respectively at Gongonboulou, Fofora and Ouly.

The Gongonboulou granite is muscovite dominant and light pink in colour. It is structured along NWN ridge, massive in the core and fractured at the contact with the volcanic rocks, infilled with auriferous quartz vein. The mineral component is largely dominated by microcline and orthose which give the pinkish coloration to the rock. The quartz is interstitial, while the plagioclase has large habitus frequently sausuritised. ghostly muscovite of centimetre size with the biotite forms some occulated minerals locally with chlorite and epidote. Abundant sulphide and iron oxide are along the networks fractures of the rock.

The second type of granitoid occurs north of Fofora locality and at Ouly as an elliptical batholith of 38x19km extension. The shape is well observable on the airborne geophysics, where the contact is border by sub-meridian strain zone. The texture is pegmatitic of quartz, microcline dominant on plagioclase and lesser biotite. Chlorite and epidote are associated to chlorite while opaque minerals in trace are related to ferromagnesian minerals.

At Ouly, the granite is medium grained, layered, locally foliated and micro folded when crossed by the shearing. Microlayers of white and dark colour of quartz-feldspar and biotite-green hornblende defined the internal texture. Chlorite deriving from mafic minerals and opaques are orientated along the foliation plane, or within the biotite cleavage. Late quartz and epidote infilling microfractures crossed scantly the regional fabrics. This rock is close to granodiorite describe by Castaing et al., 2003; Lompo, 2009 that intrude the supracrustal greenstone. 
a)

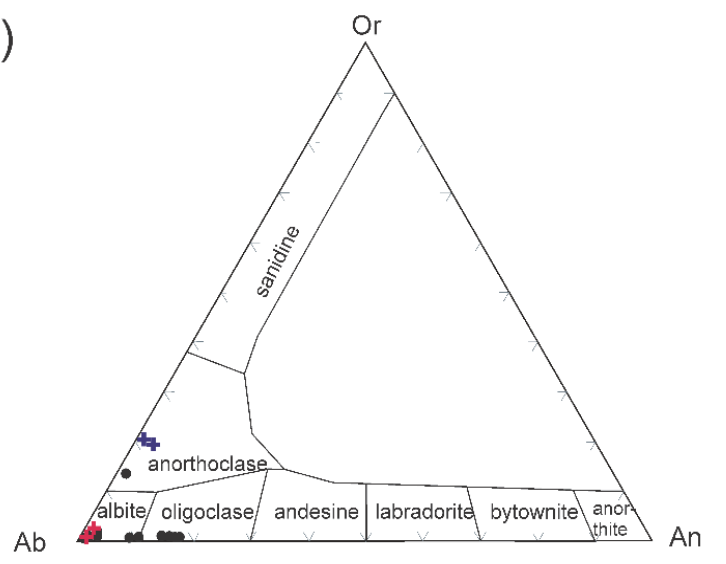

c)

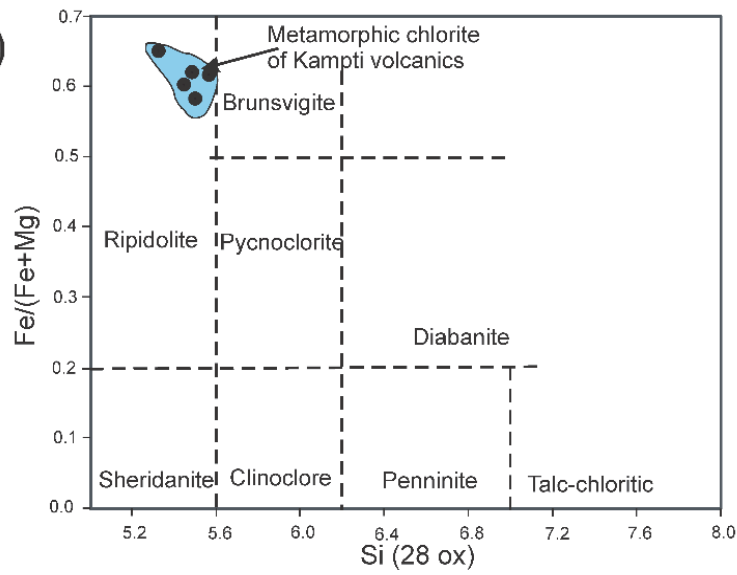

b)

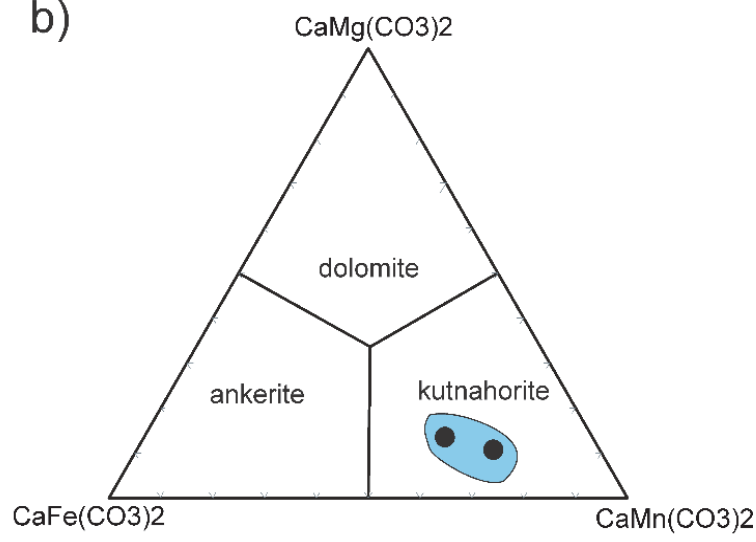

d)

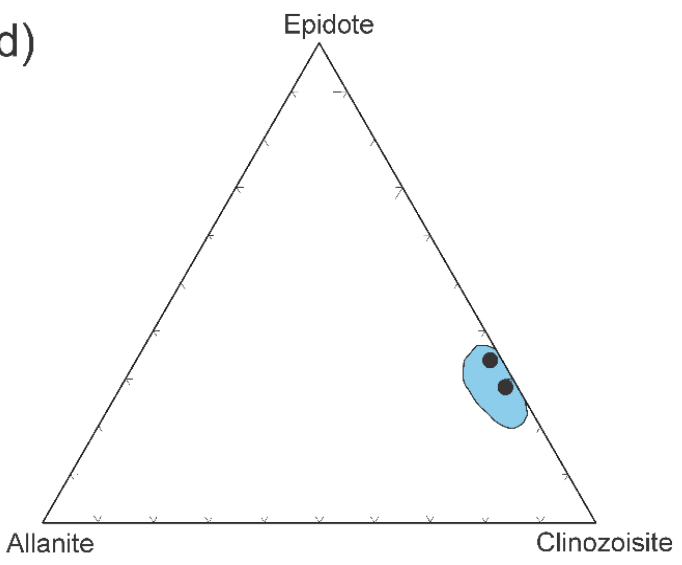

Figure 5. Mineral classification of the main paragenesis in the volcanic rocks. a) composition of plagioclase mainly of albite and oligoclase type, zoned plagioclases have an anorthoclase composition in the core (red cross)

and an albite in the outer (black cross). b) composition of calcite infilling the oolites and amygdales. c) composition of chlorite infilling the oolites and amygdales. d) composition of epidote of clinozoisite type infilling the oolites

Table 1. Chemical composition of minerals phases part of the common greenschist minerals of the volcanic rocks

\begin{tabular}{lllllllllll}
\hline Mineral species & plagioclase & & & & & & & amphibole \\
\hline $\mathrm{Sample}$ Id & NK166 & & & & & NK061 & & KR14 \\
\hline $\mathrm{SiO} 2$ & 64.401 & 69.267 & 64.455 & 67.595 & 67.099 & 66.19 & 64.866 & 65.237 & 49.716 & 51.211 \\
$\mathrm{TiO} 2$ & 0.04 & 0.011 & 0.111 & 0.005 & 0 & 0 & 0.03 & 0 & 0.157 & 0.106 \\
$\mathrm{~A} 12 \mathrm{O} 3$ & 23.93 & 20.143 & 24.203 & 20.017 & 20.747 & 21.979 & 21.624 & 21.862 & 5.891 & 4.614 \\
$\mathrm{Cr} 2 \mathrm{O} 3$ & 0.012 & 0.008 & 0.004 & 0 & 0 & 0 & 0 & 0.01 & 0 & 0 \\
$\mathrm{FeOt}$ & 1.302 & 0.144 & 1.101 & 1.056 & 0.067 & 0.122 & 0.433 & 0.049 & 16.595 & 15.933 \\
$\mathrm{MnO}$ & 0.005 & 0.052 & 0.025 & 0.053 & 0.017 & 0 & 0 & 0 & 0.312 & 0.341 \\
$\mathrm{MgO}$ & 0.386 & 0 & 0.523 & 0.064 & 0.006 & 0.006 & 0.126 & 0 & 11.67 & 12.715 \\
$\mathrm{CaO}$ & 0.226 & 0.202 & 0.461 & 0.126 & 1.388 & 2.582 & 2.382 & 2.822 & 11.8 & 11.724 \\
$\mathrm{Na} 2 \mathrm{O}$ & 7.808 & 10.681 & 6.854 & 9.594 & 10.294 & 9.752 & 9.513 & 9.894 & 0.727 & 0.866 \\
$\mathrm{~K} 2 \mathrm{O}$ & 2.89 & 0.038 & 2.453 & 0.2 & 0.07 & 0.026 & 0.036 & 0.006 & 0.104 & 0.098 \\
$\mathrm{Total}$ & 101.003 & 100.548 & 100.194 & 98.713 & 99.69 & 100.658 & 99.013 & 99.882 & 96.981 & 97.611 \\
$\mathrm{Si}$ & 11.292 & 11.986 & 11.314 & 11.939 & 11.767 & 11.537 & 11.509 & 11.483 & 7.318 & 7.455 \\
$\mathrm{Ti}$ & 0.005 & 0.001 & 0.015 & 0.001 & 0 & 0 & 0.004 & 0 & 0.017 & 0.012 \\
$\mathrm{Al}$ & 4.945 & 4.108 & 5.007 & 4.167 & 4.288 & 4.515 & 4.522 & 4.535 & 1.022 & 0.792 \\
$\mathrm{Cr}$ & 0.002 & 0.001 & 0.001 & 0 & 0 & 0 & 0 & 0.001 & 0 & 0 \\
$\mathrm{Fe}$ & 0.191 & 0.021 & 0.162 & 0.156 & 0.01 & 0.018 & 0.064 & 0.007 & -2.043 & -1.94 \\
$\mathrm{Mn}$ & 0.001 & 0.008 & 0.004 & 0.008 & 0.003 & 0 & 0 & 0 & 0.039 & 0.042 \\
$\mathrm{Mg}$ & 0.101 & 0 & 0.137 & 0.017 & 0.002 & 0.002 & 0.033 & 0 & 2.561 & 2.76 \\
$\mathrm{Ca}$ & 0.042 & 0.037 & 0.087 & 0.024 & 0.261 & 0.482 & 0.453 & 0.532 & 1.862 & 1.829
\end{tabular}




\begin{tabular}{lllllllllll}
$\mathrm{Na}$ & 2.655 & 3.583 & 2.333 & 3.286 & 3.5 & 3.296 & 3.273 & 3.377 & 0.208 & 0.245 \\
$\mathrm{~K}$ & 0.646 & 0.009 & 0.549 & 0.045 & 0.016 & 0.006 & 0.008 & 0.001 & 0.02 & 0.018 \\
$\mathrm{An}$ & 1.3 & 1.1 & 3.1 & 0.8 & 7.3 & 13.4 & 12.8 & 14.3 & & \\
$\mathrm{Ab}$ & 78.4 & 98.7 & 77.6 & 97.8 & 92.3 & 86.4 & 87 & 85.6 & & \\
$\mathrm{Or}$ & 20.3 & 0.2 & 19.4 & 1.4 & 0.4 & 0.2 & 0.2 & 0 & & \\
$(\mathrm{Ca}+\mathrm{Na})(\mathrm{B})$ & & & & & & & & & 2 & 2 \\
$\mathrm{Na}(\mathrm{B})$ & & & & & & & & & 0.138 & 0.171 \\
$(\mathrm{Na}+\mathrm{K})(\mathrm{A})$ & & & & & & & & & 0.089 & 0.091 \\
$\mathrm{Mg} /(\mathrm{Mg}+\mathrm{Fe} 2)$ & & & & & & & & & 0.603 & 0.635 \\
$\mathrm{Fe} 3 /(\mathrm{Fe}+\mathrm{Alvi})$ & & & & & & & & & & \\
\hline
\end{tabular}

\begin{tabular}{|c|c|c|c|c|c|c|c|c|c|}
\hline \multirow{2}{*}{$\begin{array}{l}\text { Mineral species } \\
\text { Sample Id }\end{array}$} & \multicolumn{5}{|c|}{ Chlorite (28 oxygen) } & \multicolumn{2}{|c|}{ carbonate ( 6 oxygen) } & \multicolumn{2}{|c|}{ Epidote $13(\mathrm{O}, \mathrm{OH})$} \\
\hline & NK166 & & & & & NK166 & & NK061 & \\
\hline $\mathrm{SiO} 2$ & 25.963 & 25.461 & 25.222 & 25.499 & 24.211 & 0.022 & 0.011 & 37.605 & 38.187 \\
\hline $\mathrm{TiO} 2$ & 0.046 & 0.021 & 0.044 & 0.018 & 0.057 & 0.050 & 0.022 & 0.137 & 1.417 \\
\hline $\mathrm{A} 12 \mathrm{O} 3$ & 21.033 & 20.984 & 20.258 & 20.409 & 20.654 & 0.029 & 0.009 & 21.493 & 22.080 \\
\hline $\mathrm{Cr} 2 \mathrm{O} 3$ & 0.091 & 0.133 & 0.087 & 0 & 0.005 & 0.014 & 0 & 0 & 0 \\
\hline $\mathrm{FeOt}$ & 29.558 & 30.444 & 30.430 & 29.998 & 30.998 & 0.322 & 0.536 & 14.145 & 12.626 \\
\hline $\mathrm{MnO}$ & 0.389 & 0.366 & 0.375 & 0.320 & 0.408 & 0.679 & 1.404 & 0.182 & 0.185 \\
\hline $\mathrm{MgO}$ & 10.723 & 11.334 & 10.964 & 11.586 & 10.563 & 0.088 & 0.150 & 0.061 & 0.063 \\
\hline $\mathrm{CaO}$ & 0.196 & 0.003 & 0.058 & 0.006 & 0.104 & 59.541 & 60.422 & 23.172 & 23.330 \\
\hline $\mathrm{Na} 2 \mathrm{O}$ & 0.069 & 0.011 & 0.120 & 0 & 0.111 & 0 & 0.022 & 0 & 0 \\
\hline $\mathrm{K} 2 \mathrm{O}$ & 0.072 & 0.042 & 0.097 & 0.028 & 0.057 & 0.000 & 0.000 & 0.024 & 0.033 \\
\hline Total & 88.140 & 88.799 & 87.656 & 87.863 & 87.166 & 60.744 & 62.576 & 96.818 & 97.921 \\
\hline $\mathrm{Si}$ & 5.564 & 5.446 & 5.484 & 5.502 & 5.325 & 0.002 & 0.001 & 3.252 & 3.237 \\
\hline $\mathrm{Ti}$ & 0.007 & 0.003 & 0.007 & 0.003 & 0.009 & 0.003 & 0.001 & 0.009 & 0.090 \\
\hline Al & 5.313 & 5.289 & 5.191 & 5.190 & 5.354 & 0.003 & 0.001 & 2.191 & 2.206 \\
\hline $\mathrm{Cr}$ & 0.015 & 0.022 & 0.015 & 0 & 0.001 & 0.001 & 0 & 0 & 0 \\
\hline $\mathrm{Fe}$ & 5.298 & 5.445 & 5.533 & 5.413 & 5.702 & 0.025 & 0.040 & 1.023 & 0.895 \\
\hline $\mathrm{Mn}$ & 0.071 & 0.066 & 0.069 & 0.059 & 0.076 & 0.053 & 0.107 & 0.013 & 0.013 \\
\hline $\mathrm{Mg}$ & 3.426 & 3.614 & 3.554 & 3.727 & 3.464 & 0.012 & 0.020 & 0.008 & 0.008 \\
\hline $\mathrm{Ca}$ & 0.045 & 0.001 & 0.014 & 0.001 & 0.025 & 5.893 & 5.824 & 2.147 & 2.119 \\
\hline $\mathrm{Na}$ & 0.029 & 0.005 & 0.1 & 0 & 0.047 & 0 & 0.004 & 0 & 0 \\
\hline $\mathrm{K}$ & 0.020 & 0.012 & 0.027 & 0.008 & 0.016 & 0 & 0 & 0.003 & 0.004 \\
\hline
\end{tabular}

\subsection{Geochemistry}

\subsubsection{Major and Trace Elements Analysis}

Geochemical datas of 17 rocks across the Kampti sector are presented in the table 2. The volcanic rocks (flows of basalt and plagioclase-phyric projection) identified on field and thin sections have a composition of sub-alkaline basalt or andesite-basalt in the $\mathrm{Zr} / \mathrm{TiO} 2 \mathrm{vs} \mathrm{Nb} / \mathrm{Y}$ plot of Winchester and Floyd, 1977 (Figure 6a). The mafic composition is related to $\mathrm{SiO} 2$ content of $47.23 \%$ to $51.09 \%$, poor in potassium $(<0.5 \%)$ and high in $\mathrm{CaO}(>7 \%$ and up to $13.74 \%$ ). In the same plots, the subvolcanic rocks are limited to rhyo-dacite and rhyolite composition. The number of magnesium $\mathrm{Mg} \#(\mathrm{Mg} / \mathrm{Mg}+\mathrm{Fe})$ for the mafic volcanics ranges $39.14 \%$ to $72.82 \%$ is sligthy higher than the mafic intrusion of the same area (Table 2). The associated intrusions comprise mostly gabbro-diorite, granite and granodiorite composition in the R1-R2 plot of De la Roche et al., 1980 (Figure 6b).

The magmatism has a bimodal character highlighted in the AFM plot and the La (ppm) vs $\mathrm{Yb}$ (ppm) of Ross \& Bediard, 2009.

(Figure $6 \mathrm{c}-\mathrm{d}$ ). The mafic rocks as volcanics and associated intrusions are all related to tholeiite affinity that is consistent with the observation of Ada et al., 2011; Baratoux et al, 2011; Augustin and Gaboury 2017; Nanema et al., 2016: Yao and al., 2017 along the same belt. The subvolcanic and felsic intrusion related to calc-alkaline affinity with a probable differentiation, as well as the tholeiite which is mostly enriched in iron $(10 \%<\mathrm{Fe} 2 \mathrm{O} 3<17 \%)$. 

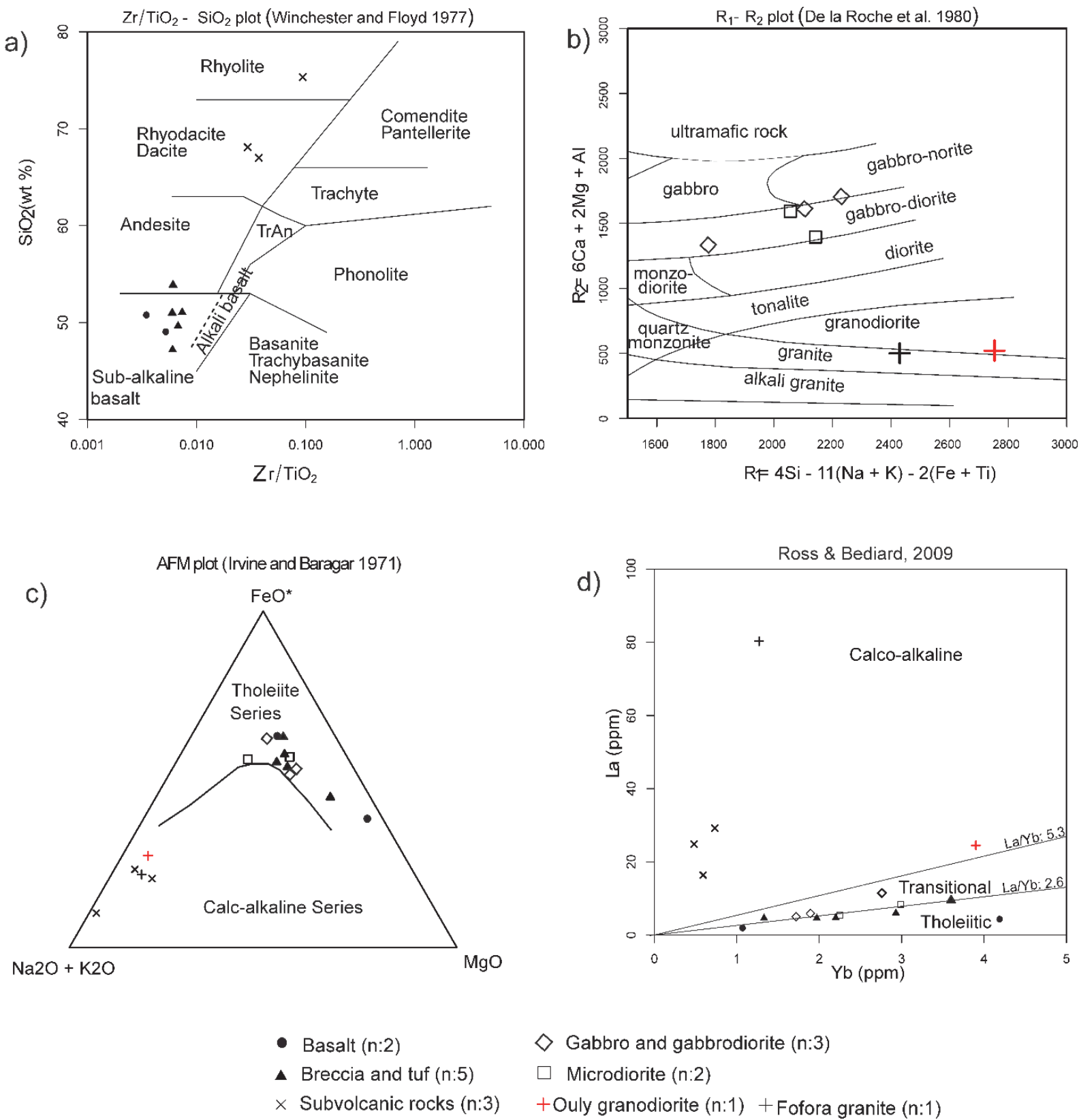

Figure 6. Classification diagrams of major and minor elements of the Kampti rocks. a) Winchester \& Floyd (1977) applied to the volcanic and subvolcanic rocks. b) De la Roche and al. (1980) applied to the plutonic rocks identified as gabbro-diorite, granite and granodiorite. c) AFM plot discriminating the magmatic affinities of the supracrustal rocks as bimodal nature. d) La vs Yb of Ross and Bediard (2009) confirms the tholeiitic and calcalkaline affinities of mafic and felsic rocks

\subsubsection{Rare Earth and Multielement Pattern}

The chondrite-normalized REE pattern (Boynton, 1984) of the tholeiitic rocks of the Kampti area comprising mafic volcanics and associated mafic intrusions display flat REE patterns with small negative $\mathrm{Dy}, \mathrm{Yb}$ anomalies and positive $\mathrm{Tb}$ (Figure 7a). In addition, the individual REE patterns are subparallel suggesting a cogenitic source of the volcanics and affiliated mafic intrusions. Such patterns are similar to N-MORB or oceanic plateau basalt signature (Abouchami et al., 1990; Beziat et al., 2000; Lompo, 2009; Ludtke et al., 1998). The normalized La/Yb ratio of the tholeiitic rocks ranges 0.7 to 2.84 , and are slightly enriched in light REE of mean 20 times to chondrite. On sample from basalt shows a less enrichment o 4 to 5 times respective to chondrite and possibly related to the fractioning of pyroxene and plagioclase. Such tholeiitic rocks are slightly enriched in $\mathrm{Eu}\left(\mathrm{Eu} / \mathrm{Eu}^{*}: 0.89\right.$ to 1.16$)$ 
with a mean accumulation of $\mathrm{Sr}$ of $239.9 \mathrm{ppm}$. In opposite, the calc-alkaline rocks (5 samples) are slightly depleted in $\mathrm{Eu}\left(\mathrm{Eu} / \mathrm{Eu}^{*}: 0.63\right.$ to 0.9$)$ and a mean concentration of $\mathrm{Sr}$ equalling 412.6ppm. Chondrite-normalized REE patterns of such calc-alkaline are discordant from the tholeiitic one, enriched 50 to 100 times in light REE respective to chondrite. The E-MORB or IAB patterns are similar to the Kampti calc-alkaline serie with $(\mathrm{La} / \mathrm{Yb})_{\mathrm{N}}$ varying 4.28 to 43.03 . The magma source could have been generated by partial melting of tholeiitic material.

The spider diagram normalised to primitive mantle from McDonough and Sun, 1995 (Figure 7b) shows relative depletion in $\mathrm{Cs}, \mathrm{Rb}, \mathrm{Th}, \mathrm{Nb}, \mathrm{Pb}, \mathrm{P}$ and $\mathrm{Ti}$. Such wide variation witness that plagioclase, pyroxene, titano-magnetite + - apatite were involved in the earlier phase of fractionation. Strong Th negative anomalies of some basalt suggest some crustal contamination of basic magmas.

\subsubsection{Geodynamic Setting}

The high field strength element like Nb, Th, Y, Zr because of their incompatibility in the mantle and their immobility to alteration and metamorphism are commonly used to describe the source the magma. In the $\mathrm{Zr} / 4$ $2 \mathrm{Nb}-\mathrm{Y}$ ) diagram of Meschede, 1986 (Figure 8a), the tholeiitic rocks plot at the limit of C and D field which share the common feature of volcanic arc basalt. Only two points of basalt are characterised as N-MORB. The ratio $\mathrm{Nb} / \mathrm{Y}$ vs. $\mathrm{Zr} / \mathrm{Y}$ plots confirm the arc related faraway of a within-plate setting (Figure 8b-c). The relative ratios $(\mathrm{Th} / \mathrm{Yb}-\mathrm{Ta} / \mathrm{Yb})$ of Schandl and Gorton, 2002 group the tholeiitic occurrences (basalt, volcanoclastic and gabbro/diorite) in MORB affinity. The granitoid is affiliated to the volcanic arc granite "VAG" like all the belt type granitoid in the $\mathrm{Nb}$ vs $\mathrm{Y}$ tectonic setting of Pearce et al., 1984 (Figure 8d).

The primary magma source can be appreciated with the ratio $\mathrm{La} / \mathrm{Ba} \mathrm{vs}$. $\mathrm{La} / \mathrm{Nb}$. The tholeiite rocks looks have a deep origin at the boundary lithosphere/ asthenosphere or below the limit. Two basalt and volcanoclastic samples have $\mathrm{La} / \mathrm{Ba}$ ratio $>0.2$ and source from the primitive mantle. The calc-alkaline rocks source on the lithosphere looks to be part of a fractionated material from the primary magma (Figure 9) or crustal and mantle mixing magma.

a)

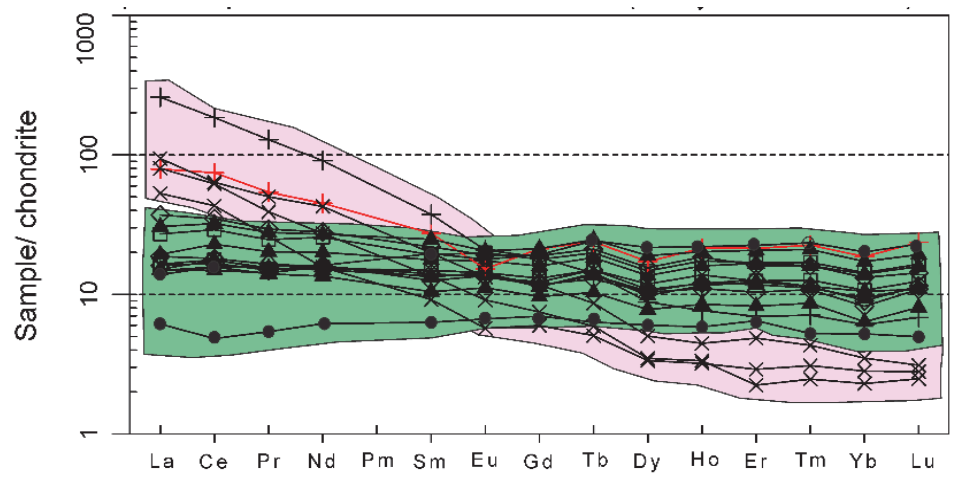

b)

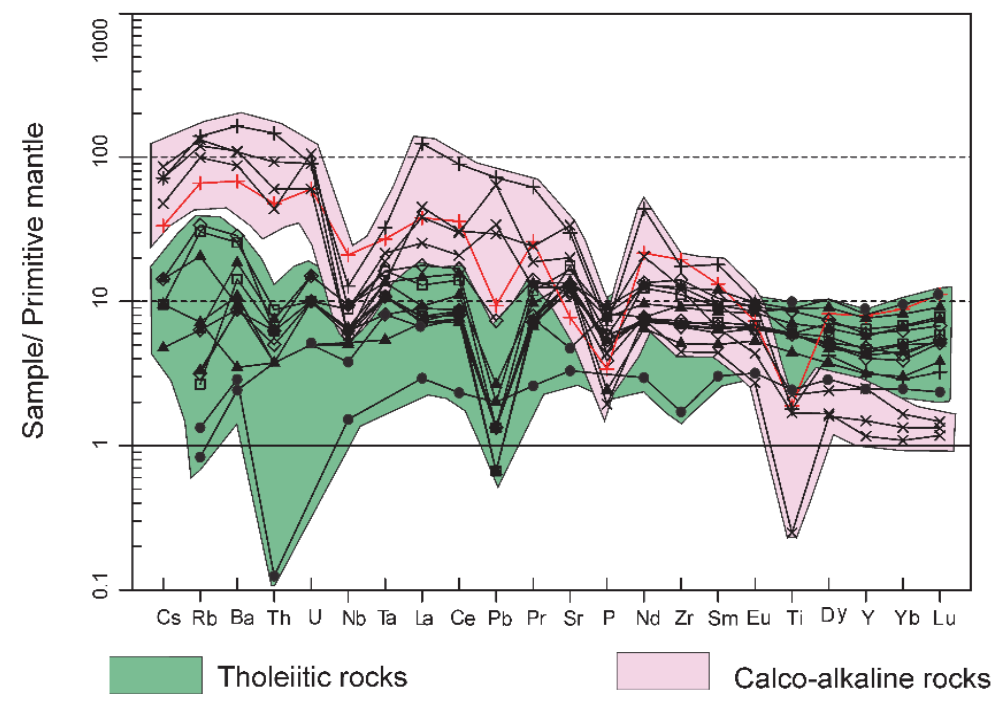

Figure 7. a) chondrite-normalized REE pattern from Boynton, 1984 and b) the spider diagram normalised to primitive mantle from McDonough and Sun, 1995 

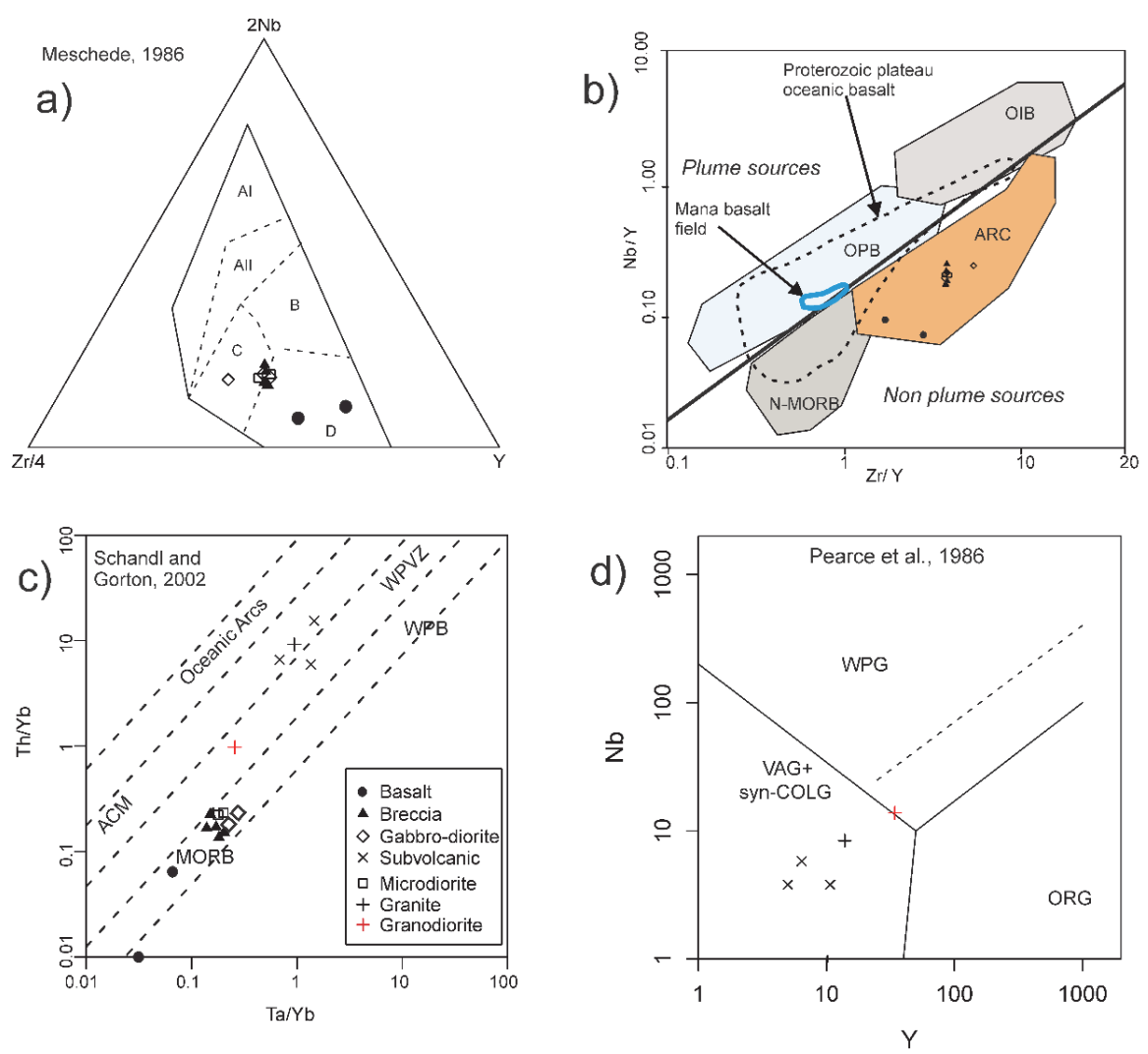

Figure 8. (a) Discrimination diagrams of Meschede 1986 applied to basic and intermediate volcanic. AI: alkalic intra-plate basalt; IIA: intra-plate alkaline basalts and tholeiitic; B: E-MORB; C: tholeiite intra-plaque and volcanic arc basalts; D: N-MORB and volcanic arc basalts. (b) $\mathrm{Nb} / \mathrm{Y}$ vs. $\mathrm{Zr} / \mathrm{Y}$ diagram. ARC: Arc-Related

Basalts; OPB: Oceanic Plateau Basalts; N-MORB: Normal-Middle Oceanic Ridge Basalt; OIB: Oceanic Island Basalt. The Proterozoic plateau oceanic basalts were obtained from Condie, 2003. (c) Geotectonic classification of volcanic rocks from Schandl and Gorton, 2002. ACM: Active Continental Margin; WPVZ: Within Plate Volcanic Zone; WPB: Within Plate Basalt. (d) Nb vs. Y tectonic discrimination of granite from Pearce et al., 1984. VAG: Volcanic Arc Group; syn-COLG: syn-Collisional Group

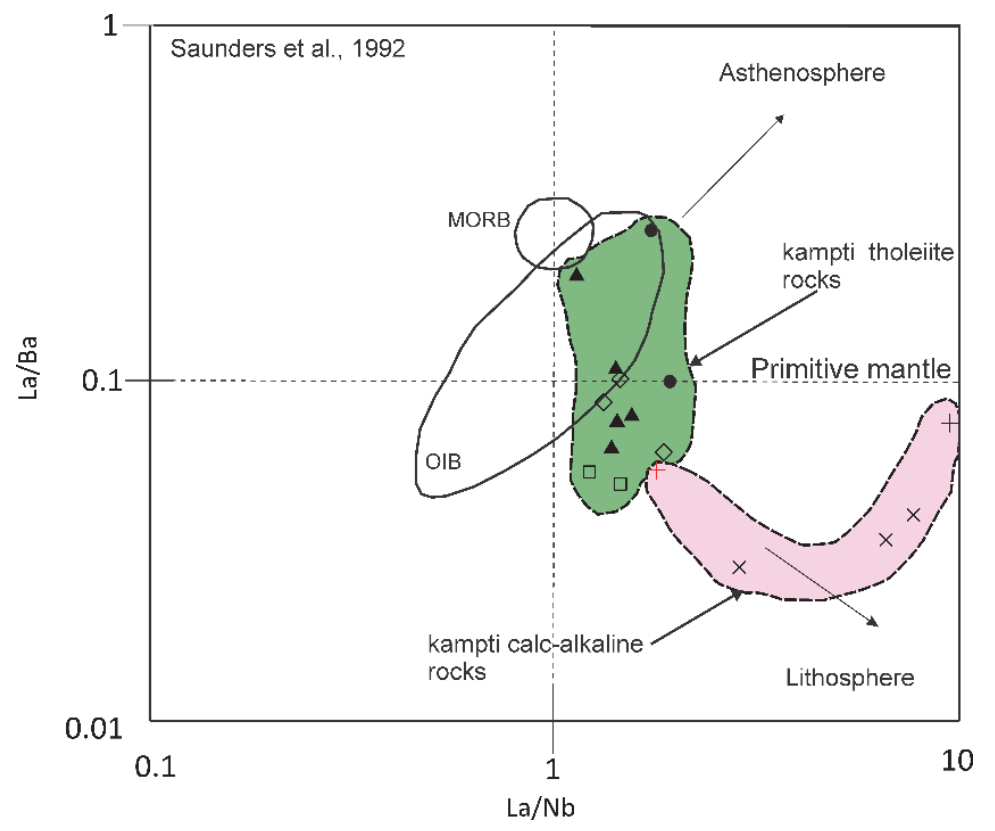

Figure 9. $\mathrm{La} / \mathrm{Ba}$ vs. $\mathrm{La} / \mathrm{Nb}$ plot for discriminating asthenosphere and lithosphere contribution (Saunder et al. 


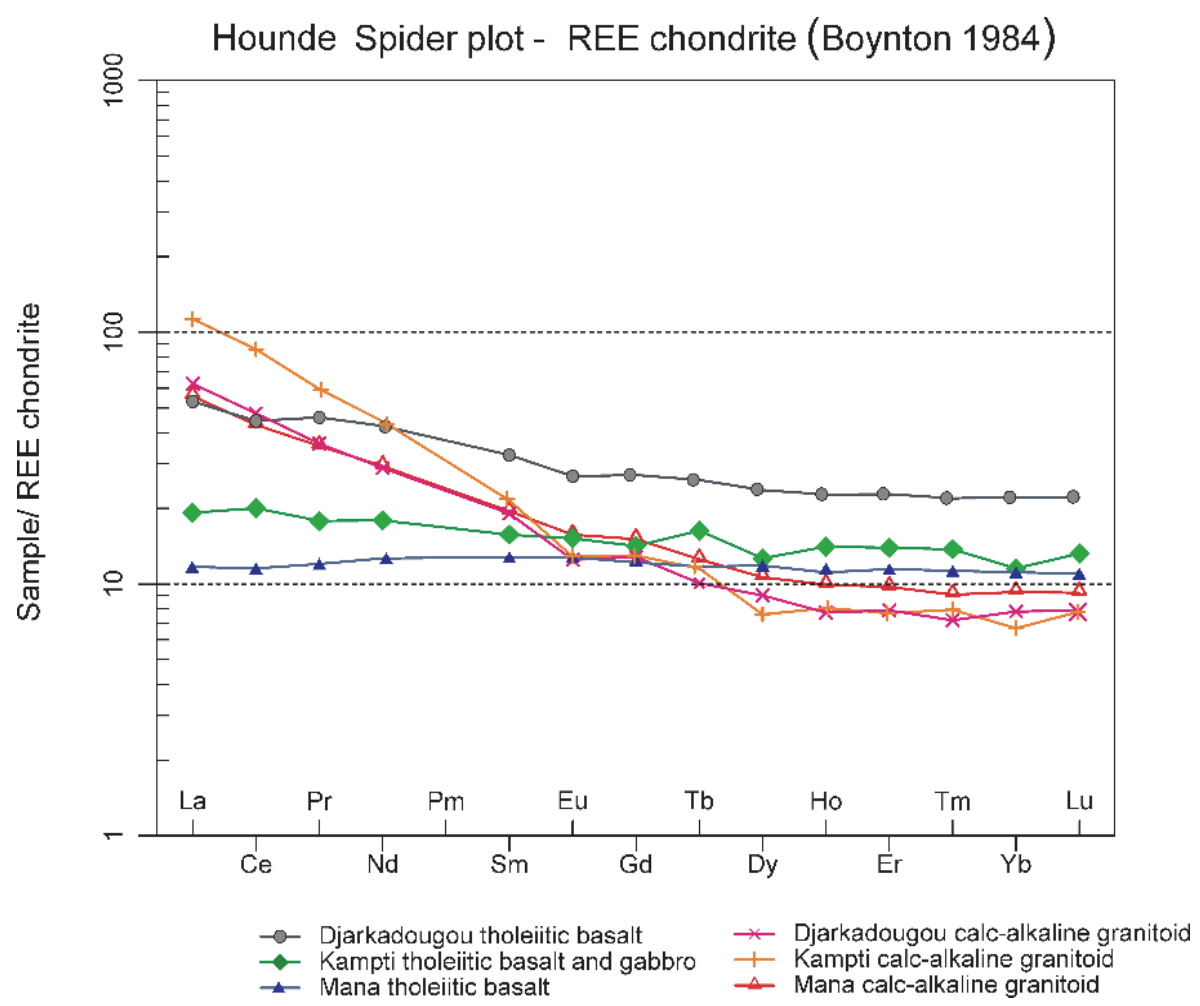

Figure 10. Mean rare earth elements pattern normalised to chondrite of tholeiitic and calc alkaline rocks of Hounde belt after Boynton (1984)

Table 2. Chemical composition of major (\%) and trace (ppm) elements of the plutono-volcanic rocks of Kampti

\begin{tabular}{llllllllllll}
\hline ID & NK045 & NK164 & \multicolumn{2}{l}{ NK015 } & NK017 & NK029 & NK030 & NK032 & NK039 & NK043 & NK055 \\
\hline Rock type & Basalt & \multicolumn{7}{l}{ Volcanic breccia } & \multicolumn{2}{l}{ Lapilli tuf } & \multicolumn{4}{l}{ Subvolcanic } \\
\hline $\mathrm{SiO} 2$ & 49.04 & 50.78 & 50.99 & 53.88 & 47.23 & 49.67 & 51.09 & 68.10 & 75.33 & 67.00 \\
$\mathrm{Al2O} 3$ & 12.60 & 5.78 & 16.97 & 14.96 & 16.20 & 16.19 & 14.84 & 15.39 & 14.01 & 14.81 \\
$\mathrm{Fe} 2 \mathrm{O} 3$ & 17.19 & 10.98 & 11.18 & 11.22 & 10.80 & 11.61 & 13.25 & 2.63 & 0.95 & 2.38 \\
$\mathrm{MgO}$ & 5.58 & 14.85 & 5.52 & 4.76 & 9.80 & 4.88 & 4.32 & 0.54 & 0.15 & 1.16 \\
$\mathrm{CaO}$ & 7.38 & 13.74 & 8.93 & 9.02 & 9.25 & 10.33 & 8.72 & 2.09 & 1.07 & 2.28 \\
$\mathrm{Na} 2 \mathrm{O}$ & 3.47 & 0.79 & 2.70 & 3.06 & 2.04 & 2.75 & 2.53 & 4.75 & 4.90 & 4.30 \\
$\mathrm{~K} 2 \mathrm{O}$ & 0.10 & 0.05 & 0.47 & 0.42 & 0.21 & 0.12 & 0.25 & 2.55 & 2.44 & 2.86 \\
$\mathrm{TiO} 2$ & 1.78 & 0.49 & 1.21 & 1.17 & 0.89 & 1.41 & 1.78 & 0.45 & 0.05 & 0.34 \\
$\mathrm{P} 2 \mathrm{O} 5$ & 0.17 & $<0.01$ & 0.11 & 0.11 & 0.05 & 0.16 & 0.19 & 0.16 & 0.04 & 0.09 \\
$\mathrm{MnO}$ & 0.25 & 0.21 & 0.17 & 0.18 & 0.15 & 0.18 & 0.24 & 0.05 & 0.02 & 0.03 \\
$\mathrm{Cr} 2 \mathrm{O} 3$ & 0.01 & 0.14 & 0.02 & 0.01 & 0.05 & 0.01 & 0.00 & $<0.002$ & $<0.002$ & 0.01 \\
$\mathrm{LOI}$ & 2.20 & 1.80 & 1.50 & 1.00 & 3.00 & 2.50 & 2.50 & 3.00 & 0.90 & 4.50 \\
$\mathrm{Mg} \#$ & 39.14 & 72.82 & 49.45 & 45.67 & 64.26 & 45.44 & 39.24 & 28.92 & 23.83 & 49.12 \\
$\mathrm{Sum}$ & 99.76 & 99.68 & 99.79 & 99.79 & 99.72 & 99.76 & 99.75 & 99.75 & 99.86 & 99.78 \\
& Trace elements & & & & & & & & \\
$\mathrm{Ni}$ & 54.00 & 424.00 & 67.00 & 64.00 & 208.00 & 40.00 & 21.00 & $<20$ & $<20$ & 29.00 \\
$\mathrm{Sc}$ & 44.00 & 59.00 & 25.00 & 22.00 & 21.00 & 36.00 & 35.00 & 4.00 & 1.00 & 5.00 \\
$\mathrm{Ba}$ & 16.00 & 19.00 & 62.00 & 23.00 & 72.00 & 57.00 & 122.00 & 727.00 & 576.00 & 714.00 \\
$\mathrm{Be}$ & $<1$ & $<1$ & $<1$ & 1.00 & $<1$ & $<1$ & $<1$ & 2.00 & $<1$ & 2.00 \\
$\mathrm{Co}$ & 59.10 & 59.20 & 50.60 & 56.30 & 64.50 & 61.50 & 58.10 & 36.30 & 33.40 & 36.80 \\
$\mathrm{Cs}$ & $<0.1$ & $<0.1$ & 0.30 & 0.20 & 0.20 & $<0.1$ & 0.10 & 1.50 & 1.00 & 1.80 \\
$\mathrm{Ga}$ & 16.80 & 7.70 & 16.90 & 14.00 & 14.70 & 17.90 & 19.60 & 17.70 & 16.60 & 16.90 \\
$\mathrm{Hf}$ & 3.00 & 0.60 & 1.90 & 1.70 & 1.50 & 2.90 & 4.10 & 4.00 & 2.10 & 3.60 \\
$\mathrm{Nb}$ & 2.50 & 1.00 & 3.30 & 4.10 & 3.40 & 4.30 & 6.20 & 3.80 & 5.80 & 3.80
\end{tabular}




\begin{tabular}{|c|c|c|c|c|c|c|c|c|c|c|}
\hline $\mathrm{Rb}$ & 0.50 & 0.80 & 12.30 & 4.30 & 4.30 & 2.00 & 3.80 & 71.50 & 59.30 & 79.00 \\
\hline $\mathrm{Sn}$ & 1.00 & $<1$ & 1.00 & 1.00 & $<1$ & 1.00 & 2.00 & 1.00 & $<1$ & 2.00 \\
\hline $\mathrm{Sr}$ & 94.40 & 65.70 & 262.00 & 241.20 & 271.60 & 272.60 & 268.20 & 669.10 & 247.60 & 399.10 \\
\hline $\mathrm{Ta}$ & 0.30 & 0.05 & 0.40 & 0.40 & 0.20 & 0.50 & 0.50 & 0.50 & 0.80 & 0.70 \\
\hline $\mathrm{Th}$ & 0.30 & 0.01 & 0.30 & 0.30 & 0.30 & 0.50 & 0.60 & 4.80 & 3.50 & 7.40 \\
\hline $\mathrm{U}$ & 0.10 & $<0.1$ & 0.10 & 0.20 & 0.10 & 0.20 & 0.30 & 1.20 & 2.10 & 1.80 \\
\hline $\mathrm{V}$ & 416.00 & 273.00 & 217.00 & 196.00 & 166.00 & 277.00 & 328.00 & 41.00 & $<8$ & 43.00 \\
\hline W & 71.70 & $<0.5$ & 109.10 & 140.90 & 80.20 & 140.60 & 214.40 & 232.80 & 248.60 & 236.00 \\
\hline $\mathrm{Zr}$ & 98.50 & 18.00 & 72.40 & 71.20 & 53.60 & 95.40 & 131.30 & 132.10 & 47.00 & 126.20 \\
\hline \multirow[t]{2}{*}{$\mathrm{Y}$} & 34.80 & 10.60 & 18.90 & 18.20 & 13.50 & 24.60 & 32.90 & 10.70 & 6.40 & 5.00 \\
\hline & \multicolumn{10}{|c|}{ Rare earth elements } \\
\hline $\mathrm{La}$ & 4.30 & 1.90 & 4.70 & 4.60 & 4.60 & 6.00 & 9.50 & 29.20 & 16.40 & 24.80 \\
\hline $\mathrm{Ce}$ & 12.70 & 3.90 & 14.20 & 12.00 & 12.70 & 18.50 & 26.00 & 51.40 & 34.90 & 50.10 \\
\hline $\operatorname{Pr}$ & 1.93 & 0.66 & 1.89 & 1.74 & 1.71 & 2.47 & 3.39 & 6.11 & 3.18 & 4.77 \\
\hline $\mathrm{Nd}$ & 9.70 & 3.70 & 9.00 & 9.50 & 8.10 & 12.00 & 16.20 & 25.60 & 9.40 & 16.40 \\
\hline $\mathrm{Sm}$ & 3.82 & 1.23 & 2.64 & 2.60 & 2.04 & 3.45 & 4.84 & 3.86 & 1.79 & 2.64 \\
\hline $\mathrm{Eu}$ & 1.31 & 0.49 & 1.02 & 1.05 & 0.82 & 1.28 & 1.51 & 0.98 & 0.42 & 0.67 \\
\hline Gd & 4.98 & 1.81 & 2.94 & 2.96 & 2.50 & 4.14 & 5.51 & 3.03 & 1.55 & 1.94 \\
\hline $\mathrm{Tb}$ & 1.15 & 0.30 & 0.67 & 0.65 & 0.49 & 0.87 & 1.17 & 0.41 & 0.24 & 0.28 \\
\hline Dy & 6.98 & 1.94 & 3.16 & 3.39 & 2.51 & 4.39 & 6.10 & 1.62 & 1.08 & 1.12 \\
\hline Ho & 1.58 & 0.42 & 0.83 & 0.87 & 0.61 & 1.15 & 1.45 & 0.32 & 0.23 & 0.24 \\
\hline $\mathrm{Er}$ & 4.72 & 1.36 & 2.58 & 2.47 & 1.73 & 3.50 & 4.35 & 1.02 & 0.61 & 0.47 \\
\hline $\mathrm{Tm}$ & 0.76 & 0.17 & 0.37 & 0.36 & 0.28 & 0.52 & 0.68 & 0.14 & 0.10 & 0.08 \\
\hline $\mathrm{Yb}$ & 4.21 & 1.09 & 2.20 & 1.97 & 1.33 & 2.93 & 3.60 & 0.73 & 0.59 & 0.48 \\
\hline $\mathrm{Lu}$ & 0.74 & 0.16 & 0.35 & 0.36 & 0.26 & 0.51 & 0.62 & 0.10 & 0.09 & 0.08 \\
\hline
\end{tabular}

(following)

\begin{tabular}{|c|c|c|c|c|c|c|c|}
\hline ID & NK013 & NK022 & NK041 & NK020 & NK046 & NK057 & NK031 \\
\hline Rock type & \multicolumn{3}{|c|}{ Gabbro-diorite } & \multicolumn{2}{|l|}{ Diorite } & Granite & Granodiorite \\
\hline $\mathrm{SiO} 2$ & 52.78 & 51.73 & 51.19 & 54.63 & 50.93 & 70.81 & 73.46 \\
\hline $\mathrm{A} 12 \mathrm{O} 3$ & 16.58 & 16.78 & 15.07 & 17.75 & 15.72 & 13.91 & 13.08 \\
\hline $\mathrm{Fe} 2 \mathrm{O} 3$ & 10.23 & 10.37 & 14.17 & 9.00 & 11.58 & 2.51 & 2.92 \\
\hline $\mathrm{MgO}$ & 5.19 & 5.67 & 4.00 & 2.62 & 5.11 & 0.81 & 0.64 \\
\hline $\mathrm{CaO}$ & 9.61 & 10.24 & 7.84 & 8.56 & 9.73 & 1.75 & 2.17 \\
\hline $\mathrm{Na} 2 \mathrm{O}$ & 2.98 & 2.48 & 2.86 & 2.96 & 2.77 & 4.11 & 4.69 \\
\hline $\mathrm{K} 2 \mathrm{O}$ & 0.28 & 0.19 & 0.94 & 0.81 & 0.10 & 3.23 & 1.67 \\
\hline $\mathrm{TiO} 2$ & 1.18 & 1.19 & 1.72 & 1.20 & 1.21 & 0.36 & 0.38 \\
\hline $\mathrm{P} 2 \mathrm{O} 5$ & 0.10 & 0.08 & 0.12 & 0.17 & 0.12 & 0.14 & 0.07 \\
\hline $\mathrm{MnO}$ & 0.16 & 0.15 & 0.18 & 0.16 & 0.17 & 0.05 & 0.06 \\
\hline $\mathrm{Cr} 2 \mathrm{O} 3$ & 0.02 & 0.02 & $<0.002$ & $<0.002$ & 0.02 & $<0.002$ & $<0.002$ \\
\hline LOI & 0.70 & 0.90 & 1.70 & 1.90 & 2.30 & 2.00 & 0.70 \\
\hline $\mathrm{Mg \#}$ & 50.13 & 52.00 & 35.87 & 36.58 & 46.64 & 39.00 & 30.28 \\
\hline \multirow[t]{2}{*}{ Sum } & 99.79 & 99.79 & 99.74 & 99.80 & 99.77 & 99.68 & 99.83 \\
\hline & \multicolumn{7}{|c|}{ Trace elements } \\
\hline $\mathrm{Ni}$ & 50.00 & 62.00 & 38.00 & $<20$ & 37.00 & $<20$ & $<20$ \\
\hline $\mathrm{Sc}$ & 29.00 & 30.00 & 29.00 & 20.00 & 31.00 & 4.00 & 7.00 \\
\hline $\mathrm{Ba}$ & 58.00 & 58.00 & 188.00 & 169.00 & 94.00 & 1080.00 & 449.00 \\
\hline $\mathrm{Be}$ & $<1$ & $<1$ & 2.00 & $<1$ & $<1$ & 3.00 & 2.00 \\
\hline $\mathrm{Co}$ & 48.50 & 50.20 & 68.00 & 41.00 & 48.70 & 38.10 & 37.70 \\
\hline Cs & $<0.1$ & $<0.1$ & 0.30 & 0.20 & $<0.1$ & 1.50 & 0.70 \\
\hline $\mathrm{Ga}$ & 16.80 & 15.90 & 18.20 & 19.20 & 17.40 & 15.60 & 14.70 \\
\hline Hf & 2.20 & 2.40 & 4.50 & 3.20 & 2.10 & 5.10 & 5.90 \\
\hline $\mathrm{Nb}$ & 4.10 & 3.80 & 6.20 & 5.80 & 4.20 & 8.40 & 13.80 \\
\hline $\mathrm{Rb}$ & 3.80 & 1.90 & 20.30 & 18.20 & 1.60 & 83.60 & 39.50 \\
\hline $\mathrm{Sn}$ & 1.00 & 1.00 & 1.00 & 1.00 & 1.00 & 1.00 & 2.00 \\
\hline
\end{tabular}




\begin{tabular}{llllllll}
\hline $\mathrm{Sr}$ & 260.80 & 236.50 & 227.00 & 329.70 & 348.90 & 593.10 & 154.20 \\
$\mathrm{Ta}$ & 0.30 & 0.40 & 0.60 & 0.60 & 0.40 & 1.20 & 1.00 \\
$\mathrm{Th}$ & 0.40 & 0.40 & 0.50 & 0.70 & 0.50 & 11.70 & 3.80 \\
$\mathrm{U}$ & 0.20 & 0.20 & 0.30 & 0.20 & 0.20 & 1.80 & 1.20 \\
$\mathrm{~V}$ & 228.00 & 217.00 & 323.00 & 154.00 & 247.00 & 38.00 & 25.00 \\
$\mathrm{~W}$ & 116.40 & 121.10 & 173.20 & 139.90 & 117.10 & 251.70 & 267.30 \\
$\mathrm{Zr}$ & 76.80 & 69.90 & 147.80 & 116.80 & 74.20 & 183.40 & 204.30 \\
$\mathrm{Y}$ & 20.60 & 17.30 & 25.60 & 27.60 & 19.90 & 13.90 & 34.20 \\
\cline { 2 - 8 } & Rare earth elements & & & & \\
\cline { 2 - 8 } $\mathrm{La}$ & 5.80 & 5.00 & 11.50 & 8.40 & 5.10 & 80.30 & 24.50 \\
$\mathrm{Ce}$ & 14.60 & 13.50 & 28.20 & 23.50 & 14.30 & 149.40 & 60.20 \\
$\mathrm{Pr}$ & 2.01 & 1.82 & 3.58 & 3.01 & 1.86 & 15.68 & 6.58 \\
$\mathrm{Nd}$ & 9.50 & 9.70 & 16.80 & 15.40 & 9.20 & 54.50 & 27.00 \\
$\mathrm{Sm}$ & 2.74 & 2.45 & 4.27 & 3.75 & 2.90 & 7.30 & 5.35 \\
$\mathrm{Eu}$ & 0.98 & 1.00 & 1.41 & 1.46 & 1.05 & 1.53 & 1.12 \\
$\mathrm{Gd}$ & 3.18 & 3.05 & 4.91 & 4.62 & 3.38 & 4.78 & 5.51 \\
$\mathrm{~Tb}$ & 0.71 & 0.61 & 1.00 & 0.94 & 0.71 & 0.67 & 1.13 \\
$\mathrm{Dy}$ & 3.49 & 3.34 & 5.01 & 4.74 & 3.82 & 2.84 & 5.53 \\
$\mathrm{Ho}$ & 0.86 & 0.79 & 1.33 & 1.25 & 0.99 & 0.55 & 1.54 \\
$\mathrm{Er}$ & 2.67 & 2.18 & 3.38 & 3.55 & 2.62 & 1.46 & 4.49 \\
$\mathrm{Tm}$ & 0.37 & 0.35 & 0.52 & 0.55 & 0.41 & 0.23 & 0.73 \\
$\mathrm{Yb}$ & 1.88 & 1.72 & 2.76 & 2.99 & 2.24 & 1.27 & 3.90 \\
$\mathrm{Lu}$ & 0.37 & 0.35 & 0.46 & 0.53 & 0.40 & 0.22 & 0.76 \\
\hline & & & & & & & \\
\hline
\end{tabular}

\section{Discussion}

\subsection{Lithostratigraphy of the Kampti Serie}

The volcanism in the Kampti area start with a massive effusion of basaltic lava followed laterally to the south by an extensive explosive activity of same nature. These volcanoclastic rocks are intercalated with subordinate flow of andesite and sheeted subvolcanic dykes of felsic composition. Related intrusion of gabbro, gabbro diorite, microdiorite are all termed tholeiitic rocks in the geochemistry chapter. Petrographic and geochemical features indicate bimodal volcanism, alternating effusion and explosion.

\subsection{Origin of the Pyroclastic Facies}

The plutono-volcanic sequence of the Kampti serie comprises a $15 \mathrm{~km}$ thick tholeiitic basalt and plagioclase-phyric volcanoclastic. Textural feature like glass shard, volcanic oolite, vitroclastic, pseudo pillow, load-cast observed within volcanoclastic is closed to pyroclastic flows. The petrography study of the pyroclastic flows showed fragments and the ground mass mineral are of same andesitic plagioclase-phyric composition. A hypothesis of a tholeiitic andesito-basalt volcanic activity took place early in the birimian magmatogenesis around $2160 \mathrm{Ma}$. The ejection of flows followed by tephra into a phreatic shallow water has been fragmented (Ricketts et al., 1982; White and Houston, 2006; Zonou, 1987) could explain the quasi-similar composition. This process temporally is perturbed by a short live ash cloud and subsequently remobilisation of these finer grains deposits can explain the thinly stratification with load clast texture.

\subsection{Constrain of the Metamorphic Regime}

The mineral components have relicts of zoning plagioclase of anorthoclase composition in the core and a rim of albite. Oligoclase has also been quantified part of the ground mass as well as the albite. Albite is interpreted to not be the primary composition of the volcanic, but part of the low grade metamorphic process. Primary minerals (feldspar, amphibole +/-pyroxene) of the plutono-volcanics has been destabilized in albite, ouralite, epidote, ripidolite type chlorite and carbonates similar to other places described in the houndé belt (Lüdtke et al., 1998., 1998; Nanema et al., 2016; Koffi et al., 2017).

\subsection{Magma Source and Geotectonic Setting}

The mineral component of the mafic volcanic and affiliated intrusions of gabbro and diorite describe on the chapter petrography are online with a tholeiitic affinity from the rock chemistry study and enriched in iron. Their REE patterns are flat and subparallel suggesting a comagmatic source like MORB or volcanic arc setting. Compared to other areas along the eastern side of the Houndé belt, Kampti tholeiite is $15-20$ times enriched, Mana is 10 times 
and Djarkadougou is 30 - 50 times (Figure 10). It looks to be a zonation of REE character around the Djarkadougou basaltic pile and could highlight different level of emplacement of the different magma chambers, or a differentiation of a solely magma originated deeper on mana area (Augustin et Gaboury, 2017 have interpreted a plume source) and enriched laterally by 2 - 5 times.

The felsic calc-alkaline occurrences (subvolcanic, granitoid) of Kampti and the others area (Figure 10) have similar REE patterns and enrichment in HREE. These rocks are probably from the same magmatic chamber and generated by the partial melting of the tholeiitic pile in long live episode of subduction.

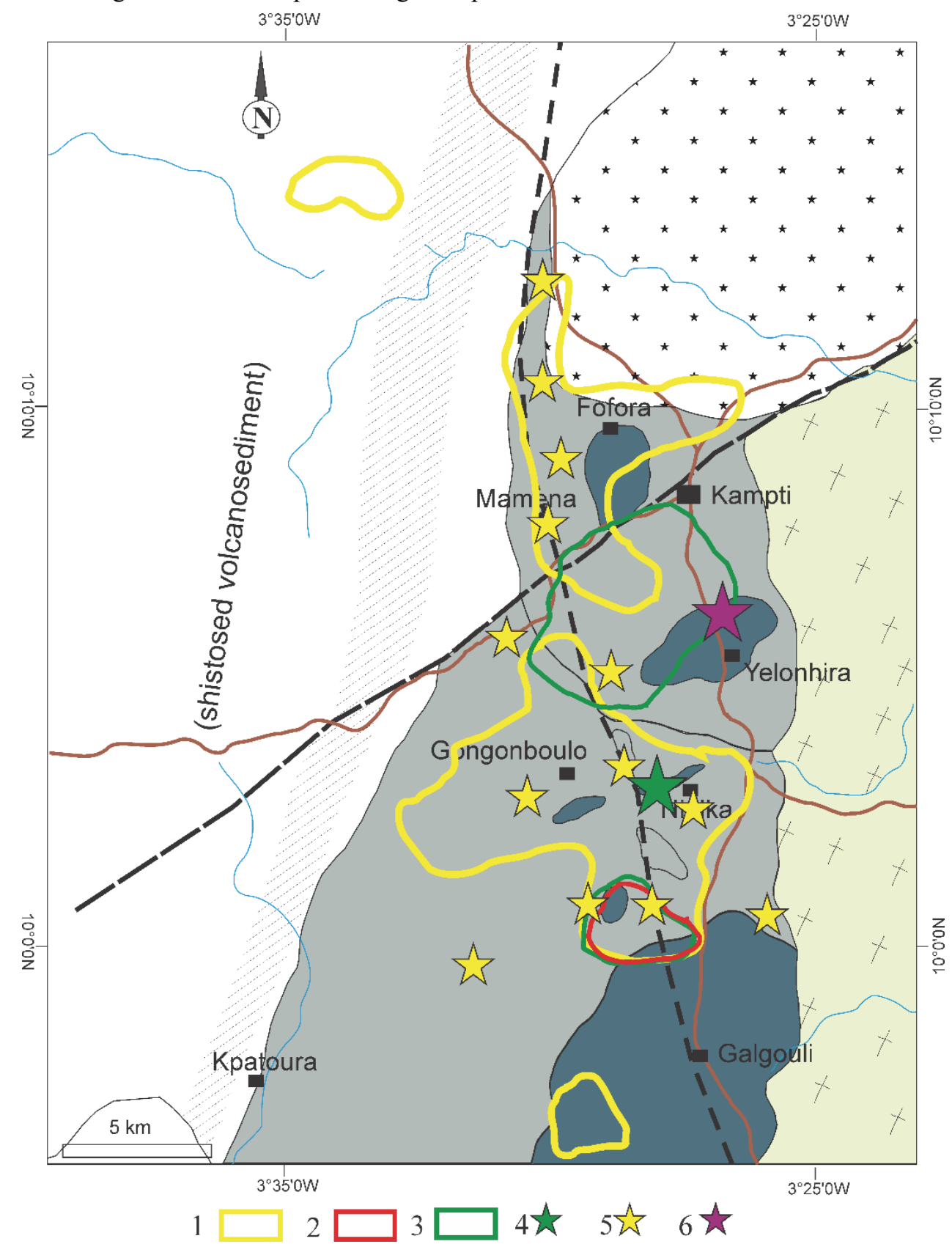

Figure 11. Metallogeny map of the Kampti district. Legend: 1) gold anomaly in soil; 2) arsenic anomaly in soil; 3) zinc anomaly in soil; 4) copper anomaly in rock; 5) gold orpaillage in rock; 6) nickel occurrence; the data are compiled from the BUMIGEB reports

\subsection{Inventory of Mineral Occurrences and Implication for Exploration}

Primary prospection has been carried on the Kampti serie since by several national geological survey and mining companies since 1954 (Kabore, 1982). Various occurrences have been highlighted by rock and soil geochemistry (Figure 11) but failed to identify economic concentration. 
Gold occurrences remain the mostly explore metal currently and suggested to intense orpaillage work. More than 10 orpaillage sites were listed in the district and spread along $20 \mathrm{~km}$ strike. Alluvial washing and shaft digging chase narrow native gold bearing quartz veins along NNW corridor. The gold concentration is structurally controlled by $2-4 \mathrm{~km}$ corridor of brittle ductile shear NNW oriented. The Fofora granite intrusion has favorited local jog and concentration of gold within subvolcanic dykes cross-cutting the basalt. High grade values have been reported from rocks chips containing significant alteration in silica - sericite - carbonate - chlorite - pyrite pyrrhotite +/- chalcopyrite +/- native gold with grade exceeding 65 grams per ton. Recent regional stream sediment carried out by the BUMIGEB confirm two anomalism sectors of Mamena-Fofora and Gongonboulou-Niolka (Figure 11) which associate arsenic anomaly. North of Kampti district, Yao and al., 2017, Ada et al., 2011, and Hein, 2015 have describe the gold mineralization of Djarkadougou and Bagassi controlled by NW - NE faults closely associated to calc-alkaline granitoid. This interaction lead to high grade gold-pyrite bearing quartz vein of $14 \mathrm{~g} / \mathrm{t}$ at Bagassi.

Nickel - cobalt - zinc occurrences have been detected in soil geochemistry (Ni: 4160 ppm, Co: 270 ppm, Cu: 750 ppm and Zn: 178 ppm) around the layered and cumulative mafic complex of Yelonhira (Nanema et al., 2016). Rocks chemistry in the complex have returned metal content of Ni: 615 ppm, Co: 86 ppm, Cu: 249 ppm et V: 414 ppm.

Copper and zinc occurrences are reported on microdiorite of Niolka and Fofora sectors. Bluish quartz and malachite, pyrite-chalcopyrite are reported from the petrographic description from the microdiorite porphyry on the dyke. Massive chalcopyrite associated to quartz vein on the basalt of Fofora, probably linked to the hydrothermal alteration associated to gold, returns copper grade $100-300 \mathrm{ppm}$ and locally $1200 \mathrm{ppm}$. Massive chalcopyrite and galena associated to quartz vein are recorded in hydrothermalised pyroclastic rocks in the locality of Kounkana.

\section{Conclusion}

The supracrustal rocks of the Kampti serie have undergone a low grade metamorphic of green schist facies at all. The bimodal nature of the magmatism is expressed by Fe-tholeiitic basalt and calc alkaline felsic magma. The normalised chondrite of the REE is flat and similar to birimian tholeiitic basalt pattern. The magmatism of the whole belt and associated granitoid is documented to be bimodal and the Kampti plutono-volcanic serie match with an accreted island arc model. The rocks chemistry, compositional, rheological contrast and proximity to the bony high strain zone agreed for a favourable mineral district confirmed by the numerous mineral occurrences discovered to date. Geology of the Mana district on the same belt is similarly documented. Recent exploration works identified mainly gold hosted in veined quartz-calcite and narrow disseminated sulphide of low economic concentration. Associated base metals have insignificant anomalies but highlight the potential for polymetallic association within the gold district. Explorers need to apply modern technics and deep drilling to success.

\section{Acknowledgement}

The authors acknowledge Randgold Resources which previously hold the Kampti 2 exploration permit for logistical support. Special thanks to Siaka Zonou for relevant discussion, Felix Kiemde, Oumar Konfe and anonymous reviewers.

\section{References}

Ada, K., Gampini, S. E., Naba, S., Marquis, P., Lompo, M., Wenmenga, U., Traoré, S. A., \& Ilboudo, H. (2011). The Djarkadougou gold deposit in the Houndé greenstone belt (Burkina-Faso - West Africa): lithological and structural context. Journal des Sciences et Technologies, 9(2), 49-64.

Augustin, J., \& Gaboury, D. (2017). Paleoproterozoic plume-related basaltic rocks in the Mana gold district in western Burkina Faso, West Africa: Implications for exploration and the source of gold in orogenic deposits. https://doi.org/10.1016/j.jafrearsci.2016.12.007ledru

Baratoux, L., Metelka, V., Naba, S., Jessell, M. W., Grégoire, M., \& Ganne, J. (2011). Juvenile Paleoproterozoic crust evolution during the Eburnean orogeny $(\sim 2.2-2.0 \mathrm{Ga})$, western Burkina Faso. Precambrian Research $191,18-45$.

Bonkoungou, I. (1994). Le Tarkwaien du sillon de Houndé (Burkina-Faso). Un ensemble volcano-détritique acide calcoalcalin à $2.15 \mathrm{Ga}$. Etude pétrologique, métamorphique et structurale. Univ. Nantes. p. 419 .

Einsenlhor, B. N., \& Hirdes, W. (1992). The structural development of the early Proterozoic Birimian and Tarkwaian rocks of southwest of Ghana, West Africa. Journal of African Earth Science, 14, 313-325.

Hein, K. A. A. (2015). The Bagassi gold deposits on the eastern margin of the Houndé greenstone belt, Burkina 
Faso, Ore Geol. Rev. https://doi.org/10.1016/j.oregeorev.2015.10.028

Irvine, T. N., \& Baragar, W. R. A. (1971). A guide to the chemical classification of the common volcanic rocks. Can. J. Earth Sci., 8, 523-548.

Kaboré, J. K. (1982). Travaux de détail pour Nickel, Cobalt et Cuivre dans la région de Kampti (zone 1, zone 2); Rapport technique BUVOGMI/PNUD.

Koffi, Y. H., Djro, S. C., \& Wenmenga, U. (2017). Lithostructural and Petrochemical Survey of Djarkadougou Gold Prospect (South West Burkina Faso / West Africa). https://doi.org/10.5539/esr.v6n1p155

Lemoine, S., (1988). Evolution géologique de la région de Dabakala (NE de la Côte d'Ivoire) au Protérozoïque inférieur. Doctorat ès Sciences, Univ. Clermont-Ferrand, 388 p.

Leube, A., Hirdes, W., Mauer, R., \& Kesse, G. O. (1990). The early Proterozoic Birimian Supergroup of Ghana and some aspects of its associated gold mineralization. Precambrian Res., 46, 139-165.

Lompo, M. (2009). Geodynamic evolution of the 2.25-2.0 Ga Paleoproterozoic magmatic rocks in the Man-Leo Shield of the West African Craton. A model of subsidence of an oceanic plateau. Geological Society, London, Special Publications, 323, 231-254. https://doi.org/10.1144/SP323.11

Lompo, M. (2010). Paleoproterozoic structural evolution of the Man-Leo Shield (West Africa). Key structures for vertical to transcurrent tectonics. Journal of African Earth Science, 58, 19-36. https://doi.org/10.1016/j.jafrearsci.2010.01.005

Ludtke, G., Hirdes, W., Konan, G., Koné, Y., Diarra, S., \& Zamblé, Z. (1998). Géologie de la région Haute Comoé Nord, avec carte géologique au 1/100.000 - Feuilles Kong (coupures $4 \mathrm{~b}$ et $4 \mathrm{~d}$ ) et Téhini-Bouna (coupures $3 \mathrm{a}$ et 3d), 1ère édition. Rep. $\mathrm{N}^{\circ} 112713$, Arch. BGR, 157p.

Markwitz, V., Hein, K. A. A., \& Miller, J. (2015). Compilation of West African minerals deposits: spatial distribution and mineral endowment. Precambrian Res., 274, 61-81. http://dx.doi.org/10.1016/j.precamres.2015.05.028

Meschede, M. (1986). A method of discriminating between different types of mid-ocean ridge basalts and continental tholeiites with the Nb-Zr-Y diagram. Chem. Geol., 56, 207-218. https://doi.org/10.1016/00092541(86)90004-5

Milési, J. P., Diallo, M., Feybesse, J. L., Keita, F., Ledru, P., Vinchon, C., \& Dommanget, A. (1986). Caractérisation lithostructurale de deux ensembles successifs dans les séries birimiennes de la fenêtre de Kédougou (SénégalMali) et du Niandian (Guinée) : implications gîtologiques. Publications Occasionnelles CIFEG, Paris, 10, 113-121.

Nanema, M., Koffi, H. Y., \& Wenmenga, U. (2016). Étude pétrochimique et géodynamique du complexe mafique de Yelonhira dans la zone Sud du sillon de Houndé, Burkina Faso, Afrique de l'Ouest. Afrique Science, 12(4), 314-333.

Ricketts, B. D., Ware, M. J., \& Donaldson, J. A. (1982). Volcaniclastic rocks and Volcaniclastic facies in the Middle Precambrian (Aphebian) Belcher Group, Northwest Territories, Canada. Can. J. Earth Sci., 19, 1275-1294. https://doi.org/10.1139/e82-109

Sattran, V., \& Wenmenga, U. (2002). Géologie du Burkina Faso/ Geology of Burkina Faso. Czech Geological Survey, $136 \mathrm{p}$.

Wenmenga, U., \& Affaton, P. (2003). Les anomalies géochimiques ( $\mathrm{Pb}-\mathrm{Zn}-\mathrm{Cu})$ du district métallogénique de la région de Gaoua, ceinture Birimienne de Poura Burkina-Faso. Journal of Mining and Geology. Nigeria Mining and Geosciences society (NMGS)-Printed in Nigeria, 39(1), 29-38. https://doi.org/10.4314/jmg.v39i1.18788

Zonou, S. (1987). Les formations leptyno-amphibolitiques et le complexe volcanique et volcano-sédimentaire du Protérozoïque Inférieur de Bouroum-Nord (Burkina-Faso Afrique de l'Ouest). Unpublished Ph.D. thesis, Université de Nancy, 294 p.

\section{Copyrights}

Copyright for this article is retained by the author(s), with first publication rights granted to the journal.

This is an open-access article distributed under the terms and conditions of the Creative Commons Attribution license (http://creativecommons.org/licenses/by/4.0/). 